\title{
Global impact of mineral dust on cloud droplet number concentration
}

\author{
Vlassis A. Karydis ${ }^{1}$, Alexandra P. Tsimpidi ${ }^{1}$, Sara Bacer ${ }^{1}$, Andrea Pozzer ${ }^{1}$, Athanasios Nenes ${ }^{2,3,4}$, and Jos Lelieveld ${ }^{1,5}$ \\ ${ }^{1}$ Department of Atmospheric Chemistry, Max Planck Institute for Chemistry, Mainz, 55128, Germany \\ ${ }^{2}$ School of Earth and Atmospheric Sciences and School of Chemical and Biomolecular Engineering, \\ Georgia Institute of Technology, Atlanta, GA, 30332, USA \\ ${ }^{3}$ Institute of Environmental Research and Sustainable Development, National Observatory of Athens, \\ Palea Penteli, 15236, Greece \\ ${ }^{4}$ Institute for Chemical Engineering Sciences, Foundation for Research and Technology Hellas, Patras, 26504, Greece \\ ${ }^{5}$ Energy, Environment and Water Research Center, The Cyprus Institute, Nicosia, 1645, Cyprus
}

Correspondence to: Vlassis A. Karydis (v.karydis@mpic.de)

Received: 22 November 2016 - Discussion started: 16 December 2016

Revised: 24 March 2017 - Accepted: 28 March 2017 - Published: 3 May 2017

\begin{abstract}
The importance of wind-blown mineral dust for cloud droplet formation is studied by considering (i) the adsorption of water on the surface of insoluble particles, (ii) particle coating by soluble material (atmospheric aging) which augments cloud condensation nuclei (CCN) activity, and (iii) the effect of dust on inorganic aerosol concentrations through thermodynamic interactions with mineral cations. The ECHAM5/MESSy Atmospheric Chemistry (EMAC) model is used to simulate the composition of global atmospheric aerosol, while the ISORROPIA-II thermodynamic equilibrium model treats the interactions of $\mathrm{K}^{+}$$\mathrm{Ca}^{2+}-\mathrm{Mg}^{2+}-\mathrm{NH}_{4}^{+}-\mathrm{Na}^{+}-\mathrm{SO}_{4}^{2-}-\mathrm{NO}_{3}^{-}-\mathrm{Cl}^{-}-\mathrm{H}_{2} \mathrm{O}$ aerosol with gas-phase inorganic constituents. Dust is considered a mixture of inert material with reactive minerals and its emissions are calculated online by taking into account the soil particle size distribution and chemical composition of different deserts worldwide. The impact of dust on droplet formation is treated through the "unified dust activation parameterization" that considers the inherent hydrophilicity from adsorption and acquired hygroscopicity from soluble salts during aging. Our simulations suggest that the presence of dust increases cloud droplet number concentration (CDNC) over major deserts (e.g., up to $20 \%$ over the Sahara and the Taklimakan desert) and decreases CDNC over polluted areas (e.g., up to $10 \%$ over southern Europe and $20 \%$ over northeastern Asia). This leads to a global net decrease in CDNC by $11 \%$. The adsorption activation of insoluble aerosols and the min-
\end{abstract}

eral dust chemistry are shown to be equally important for the cloud droplet formation over the main deserts; for example, these effects increase CDNC by $20 \%$ over the Sahara. Remote from deserts the application of adsorption theory is critically important since the increased water uptake by the large aged dust particles (i.e., due to the added hydrophilicity by the soluble coating) reduce the maximum supersaturation and thus cloud droplet formation from the relatively smaller anthropogenic particles (e.g., CDNC decreases by $10 \%$ over southern Europe and $20 \%$ over northeastern Asia by applying adsorption theory). The global average CDNC decreases by $10 \%$ by considering adsorption activation, while changes are negligible when accounting for the mineral dust chemistry. Sensitivity simulations indicate that CDNC is also sensitive to the mineral dust mass and inherent hydrophilicity, and not to the chemical composition of the emitted dust.

\section{Introduction}

Atmospheric aerosols from anthropogenic and natural sources adversely affect human health and influence the Earth's climate, both directly and indirectly (Haywood and Boucher, 2000; Lohmann and Feichter, 2005; Andreae and Rosenfeld, 2008; IPCC, 2013; Kushta et al., 2014; Lelieveld et al., 2015). The direct climate effect refers to the influence of aerosols on the radiative budget of Earth's atmo- 
sphere by scattering and absorbing solar radiation (Seinfeld and Pandis, 2006). The indirect effects include the ability of aerosols to affect the cloud optical thickness and scattering properties of clouds (Twomey, 1974) as well as the cloud lifetime and precipitation (Albrecht, 1989). The scientific interest in aerosol-cloud-climate interactions initially focused on anthropogenic pollutants (e.g., sulfate) and to a lesser extent on naturally emitted aerosols (e.g., sea salt). However, among atmospheric aerosols, mineral dust is of particular importance since it is globally dominant in terms of mass concentration in the atmosphere (Grini et al., 2005; Zender and Kwon, 2005) and can influence cloud and precipitation formation (Levin et al., 2005; Yin and Chen, 2007; Karydis et al., 2011a; Rosenfeld et al., 2011; Kallos et al., 2014). Additionally, dust alone is responsible for more than 400000 deaths attributable to air pollution per year (Giannadaki et al., 2014).

Freshly emitted dust is considered insoluble. Reports of hygroscopic growth measurements of dust particles indicate solubility to be very low, so that activation of observed cloud condensation nuclei $(\mathrm{CCN})$ has been attributed to soluble ions present in the particles (Gustafsson et al., 2005; Herich et al., 2009; Koehler et al., 2009; Garimella et al., 2014). Chemistry-climate models (CCMs) typically use Köhler theory to describe droplet formation from dust, which assumes that the $\mathrm{CCN}$ activity depends solely on their curvature effect and the fraction of soluble material on the particle (Smoydzin et al., 2012). However, mineral dust can adsorb water which results in a surface film of water with reduced activity (Sorjamaa and Laaksonen, 2007), and promote the formation of cloud droplets at cloud-relevant supersaturation, even of freshly emitted and chemically unprocessed dust particles (Sorjamaa and Laaksonen, 2007; Kumar et al., 2009a). Kumar et al. (2009a) emphasized the importance of including water adsorption effects in describing the hygroscopic growth of mineral aerosols, which was then included in a droplet formation parameterization (Kumar et al., 2009b) for use in models. Evidence on the importance of adsorption activation of dust particles is discussed in Kumar et al. (2011b, a) for dry- and wet-generated clays and mineral dusts representative of major regional dust sources (North Africa, East Asia and North America). Adsorption activation was also found to be important for volcanic ashes (Lathem et al., 2011). The observed hygroscopicity could not be attributed to the soluble ions present but rather to the strong water vapor adsorption on the particle surface. Furthermore, the surface fractal dimension derived from dust and ash critical supersaturation data agrees well with previous methods based on measurements of nitrogen adsorption, which contribute strong evidence for adsorption effects on water activity and droplet activation (Laaksonen et al., 2016), despite concerns raised by Garimella et al. (2014) on multiple charging effects on the work of Kumar et al. (2011b).

Hatch et al. (2014) provided an alternative approach for parameterizing $\mathrm{CCN}$ activation of fresh atmospheric min- eral aerosol. This approach was based on experimental water adsorption measurements on mineral clays compared to CCN measurements used by Kumar et al. (2011b), which require corrections for multiply charged particles and nonsphericity. Despite differences in the adsorption parameters reported from the above two studies, the adsorption derived $\mathrm{CCN}$ activities were quite similar and in excellent agreement.

Based on these findings, Karydis et al. (2011a) integrated the Kumar et al. (2009b) parameterization into the Global Modeling Initiative (GMI) chemical transport model (Considine et al., 2005) and found that insoluble mineral dust can contribute up to $24 \%$ of the cloud droplet number downwind of arid areas. Subsequently, the Kumar et al. (2009b) parameterization has been integrated in a number of global and regional models and applied to investigate the impact of mineral dust on warm cloud formation (Bangert et al., 2012; Karydis et al., 2012; Gantt et al., 2014; Zhang et al., 2015).

Soluble inorganic ions like $\mathrm{Ca}^{2+}, \mathrm{Mg}^{2+}, \mathrm{Na}^{+}$, and $\mathrm{K}^{+}$ that exist on the surface of mineral dust particles can participate in heterogeneous chemical reactions with acids such as $\mathrm{HNO}_{3}$ and $\mathrm{HCl}$. Furthermore, dust particles can provide reaction sites for the $\mathrm{SO}_{2}$ oxidation into $\mathrm{H}_{2} \mathrm{SO}_{4}$. These processes result in the coating of dust particles by soluble material, which augments the hygroscopicity of dust and therefore its ability to act as CCN (Kelly et al., 2007). On the other hand, highly oxidized, soluble organic species, particularly including carboxylic acid groups (e.g., oxalic acid), can interact with particles dominated by divalent salts (e.g., $\mathrm{CaCl}_{2}$ ) and strongly decrease their hygroscopicity (Drozd et al., 2014). Due to their relatively large size, chemically aged dust particles can act as giant $\mathrm{CCN}$, enhancing precipitation as they efficiently collect moisture and grow at the expense of smaller droplets (Feingold et al., 1999; Levin et al., 2005). In addition, giant $\mathrm{CCN}$ compete with the submicron particles for water vapor, potentially reducing supersaturation and cloud droplet formation (Barahona et al., 2010; Morales Betancourt and Nenes, 2014b, a).

Soluble coatings on dust are mostly evident in the atmosphere after long-range transport of dust plumes. Anthropogenic $\mathrm{NO}_{3}^{-}$and $\mathrm{SO}_{4}^{2-}$ mainly contribute to the chemical aging of dust over continents, while sea-salt-derived $\mathrm{Cl}^{-}$is more important over oceans (Sullivan et al., 2007; Fountoukis et al., 2009; Dall'Osto et al., 2010; Tobo et al., 2010; Karydis et al., 2011b; Bougiatioti et al., 2016b; Weber et al., 2016). Apart from the gas-phase composition, the chemical processing of dust also depends on its chemical composition and thus on the source region (Sullivan et al., 2009; Karydis et al., 2016). Several studies have revealed that Saharan dust can be efficiently transported over the Mediterranean Basin, where it can acquire significant soluble coatings (mostly sea salt and sulfate) resulting in the enhancement of its hygroscopicity and CCN activity (Wurzler et al., 2000; Falkovich et al., 2001; Smoydzin et al., 2012; Abdelkader et al., 2015). Twohy et al. (2009) have shown that Saharan dust often acts as CCN over the eastern North Atlantic and 
significantly contributes to cloud formation west of Africa. Bègue et al. (2015) analyzed a case of possible mixing of European pollution aerosols with Saharan dust transported over northern Europe, and found that aged Saharan dust was sufficiently soluble to impact the hygroscopic growth and cloud droplet activation over the Netherlands. Asian dust has also been reported to have a considerable impact on cloud formation after being transported over long distances and mixed with soluble materials (Perry et al., 2004; Roberts et al., 2006; Sullivan et al., 2007; Ma et al., 2010; Stone et al., 2011; Yamashita et al., 2011).

Despite the importance of mineral dust aerosol chemistry for accurately predicting the aerosol hygroscopicity changes that accompany these reactions, most thermodynamic models used in global studies lack a realistic treatment of crustal species, e.g., assuming that mineral dust is chemically inert (Liao et al., 2003; Martin et al., 2003; Koch et al., 2011; Leibensperger et al., 2012). Few global studies have accounted for the thermodynamic interactions of crustal elements with inorganic aerosol components (Feng and Penner, 2007; Fairlie et al., 2010; Xu and Penner, 2012; Hauglustaine et al., 2014; Karydis et al., 2016). Most of these models either neglect the impact of dust on cloud droplet formation or apply simplified assumptions about the CCN activity of dust, e.g., they convert "hydrophobic" dust to "hydrophilic" dust by applying a constant $\kappa$-hygroscopicity (e.g., 0.1 ) and use Köhler theory to describe cloud droplet activation. However, accounting for both the inherent hydrophilicity of dust and the acquired hygroscopicity from soluble salts could improve the predictive capability of CCMs. For this purpose, Kumar et al. (2011a) presented a "unified dust activation framework" (UAF) to treat the activation of dust with substantial amounts of soluble material by considering the effects of adsorption (due to the hydrophilicity of the insoluble core) and absorption (due to the hygroscopicity of the soluble coating) on CCN activity. Karydis et al. (2011a) provided a first estimate of aged dust contribution to global CCN and cloud droplet number concentration (CDNC) by using the UAF. They found that coating of dust by hygroscopic salts can cause a 2-fold enhancement of its contribution to $\mathrm{CCN}$. On the other hand, aged dust can substantially deplete in-cloud supersaturation and hence reduce the CDNC. Bangert et al. (2012) investigated the impact of Saharan dust on cloud droplet formation over western Europe and found only a slight increase in calculated CDNC. However, these studies did not include thermodynamic interactions of mineral dust with sea salt and anthropogenic pollutants. Instead, a prescribed fraction of mineral dust that is coated with ammonium sulfate was used to represent the aged dust.

The present work aims at advancing previous studies of dust influences on cloud droplet formation by comprehensively considering (i) the adsorption of water on the surface of insoluble dust particles, (ii) the coating of soluble material on the surface of mineral particles which augments their CCN activity, and (iii) the effects of dust on the inor- ganic soluble fraction of dust through thermodynamic interactions of semi-volatile inorganic species and sulfate with mineral cations. The ECHAM5/MESSy Atmospheric Chemistry (EMAC) model (Jöckel et al., 2006) is used to simulate aerosol processes, while the "unified dust activation framework" (Karydis et al., 2011a; Kumar et al., 2011a) is applied to calculate the $\mathrm{CCN}$ spectra and droplet number concentration by explicitly accounting for the inherent hydrophilicity from adsorption and acquired hygroscopicity from soluble salts by dust particles from atmospheric aging. Mineral dust chemistry has been taken into account by using the thermodynamic equilibrium model ISORROPIA II (Fountoukis and Nenes, 2007). Dust emissions are calculated online by an advanced dust emission scheme that accounts for the soil particle size distribution (Astitha et al., 2012) and chemical composition (Karydis et al., 2016) of different deserts worldwide. The sensitivity of the simulations to the emitted dust aerosol load, the mineral dust chemical composition and the inherent hydrophilicity of mineral dust is also considered.

\section{Model description}

\subsection{EMAC model}

We used the ECHAM5/MESSy Atmospheric Chemistry (EMAC) model (Jöckel et al., 2006), which uses the Modular Earth Submodel System (MESSy2) (Jöckel et al., 2010) to connect submodels that describe the lower and middle atmosphere processes with the fifth-generation European Centre - Hamburg (ECHAM5) general circulation model (GCM) as a dynamical core (Röckner et al., 2006). EMAC has been extensively described and evaluated against in situ observations and satellite retrievals (de Meij et al., 2012; Pozzer et al., 2012; Karydis et al., 2016; Tsimpidi et al., 2017). The spectral resolution of the EMAC model used in this study is T63L31, corresponding to a horizontal grid resolution of approximately $1.9^{\circ} \times 1.9^{\circ}$ and 31 vertical layers between the surface and $10 \mathrm{hPa}$ (i.e., $25 \mathrm{~km}$ altitude). The model dynamics has been weakly nudged (Jeuken et al., 1996) towards the analysis data of the European Centre for MediumRange Weather Forecasts (ECMWF) operational model (up to $100 \mathrm{hPa}$ ) to represent the actual day-to-day meteorology in the troposphere. EMAC is applied for 2 years covering the period 2004-2005, and the first year is used as spin-up.

EMAC simulates the gas-phase species through the MECCA submodel (Sander et al., 2011). Aerosol microphysics are calculated by the GMXe module (Pringle et al., 2010). The organic aerosol formation and chemical aging are calculated by the ORACLE submodel (Tsimpidi et al., 2014). The CLOUD submodel (Röckner et al., 2006) calculates the cloud cover as well as cloud microphysics and precipitation of large-scale clouds (i.e., excluding convective clouds). The cloud microphysical processes are computed by using the detailed two-moment liquid and ice-cloud microphysical 
scheme described in Lohmann and Ferrachat (2010), which enables a physically based treatment of aerosol-cloud interactions. The wet and dry deposition are calculated by the SCAV (Tost et al., 2006) and the DRYDEP (Kerkweg et al., 2006) submodels.

The inorganic aerosol composition is computed with the ISORROPIA-II (http://isorropia.eas.gatech.edu) thermodynamic equilibrium model (Fountoukis and Nenes, 2007) with updates as discussed in Capps et al. (2012). ISORROPIA-II calculates the gas-liquid-solid equilibrium partitioning of the $\mathrm{K}^{+}-\mathrm{Ca}^{2+}-\mathrm{Mg}^{2+}-\mathrm{NH}_{4}^{+}-\mathrm{Na}^{+}-\mathrm{SO}_{4}^{2-}-\mathrm{NO}_{3}^{-}$$\mathrm{Cl}^{-}-\mathrm{H}_{2} \mathrm{O}$ aerosol system. Potassium, calcium, magnesium, and sodium are assumed to exist in the form of $\mathrm{Ca}\left(\mathrm{NO}_{3}\right)_{2}$, $\mathrm{CaCl}_{2}, \mathrm{CaSO}_{4}, \mathrm{KHSO}_{4}, \mathrm{~K}_{2} \mathrm{SO}_{4}, \mathrm{KNO}_{3}, \mathrm{KCl}, \mathrm{MgSO}_{4}$, $\mathrm{Mg}\left(\mathrm{NO}_{3}\right)_{2}, \mathrm{MgCl}_{2}, \mathrm{NaHSO}_{4}, \mathrm{Na}_{2} \mathrm{SO}_{4}, \mathrm{NaNO}_{3}$, and $\mathrm{NaCl}$ in the solid phase and $\mathrm{Ca}^{2+}, \mathrm{K}^{+}, \mathrm{Mg}^{2+}$, and $\mathrm{Na}^{+}$in the aqueous phase. More details about the EMAC model setup used in this study can be found in Karydis et al. (2016).

\subsection{CCN activity and cloud droplet formation parameterization}

The cloud droplet formation parameterization is triggered only when warm clouds are present (i.e., cloud water is present and temperature exceeds $269 \mathrm{~K}$ ). The equilibrium supersaturation, $s$, over the surface of a water droplet containing a solute particle (i.e., without any insoluble material present) is calculated using the hygroscopicity parameter, $\kappa$, based on $\kappa$-Köhler theory (KT) (Petters and Kreidenweis, 2007):

$s=\frac{4 \sigma M_{\mathrm{w}}}{R T \rho_{\mathrm{w}} D_{\mathrm{P}}}-\frac{D_{\mathrm{dry}}^{3} \kappa}{D_{\mathrm{P}}^{3}}$,

where $D_{\text {dry }}$ is the dry CCN diameter, $D_{\mathrm{P}}$ is the droplet diameter, $\sigma$ is the CCN surface tension at the point of activation, $\rho_{\mathrm{w}}$ is the water density, $M_{\mathrm{w}}$ is the molar mass of water, $R$ is the universal gas constant, and $T$ is the average column temperature.

For insoluble particles (e.g., pristine mineral dust), the multilayer Frenkel-Halsey-Hill (FHH) adsorption isotherm model (Sorjamaa and Laaksonen, 2007) is used, which contains two adjustable parameters $\left(A_{\mathrm{FHH}}\right.$ and $\left.B_{\mathrm{FHH}}\right)$ that describe the contribution of water vapor adsorption on $\mathrm{CCN}$ activity. In this case, the equation describing the equilibrium supersaturation over the surface of a water droplet is given by (Kumar et al., 2009b)

$s=\frac{4 \sigma M_{\mathrm{w}}}{R T \rho_{\mathrm{w}} D_{\mathrm{P}}}-A_{\mathrm{FHH}}\left(\frac{D_{\mathrm{P}}-D_{\mathrm{dry}}}{2 D_{\mathrm{w}}}\right)^{-B_{\mathrm{FHH}}}$,

where $D_{\mathrm{w}}$ is the diameter of a water molecule. The adsorption parameter $A_{\mathrm{FHH}}$ represents the interactions between the first water monolayer and the dust surface. $B_{\mathrm{FHH}}$ expresses the long-range interactions of additional adsorbed water layers with the dust surface. Kumar et al. (2011b) tested a wide range of fresh unprocessed regional dust samples and minerals and found that one set of the FHH parameters $\left(A_{\mathrm{FHH}}=\right.$ $2.25 \pm 0.75, B_{\mathrm{FHH}}=1.20 \pm 0.10$ ) adequately reproduces the measured CCN activity for all dust types considered.

To account for the coating of soluble material on the surface of mineral dust, the "unified activation framework" (Karydis et al., 2011a; Kumar et al., 2011a) is used, which describes the water vapor supersaturation over an aerosol particle consisting of insoluble core with a soluble coating:

$$
s=\frac{4 \sigma M_{\mathrm{w}}}{R T \rho_{\mathrm{w}} D_{\mathrm{P}}}-\frac{\varepsilon_{\mathrm{s}} D_{\mathrm{dry}}^{3} \kappa}{\left(D_{\mathrm{P}}^{3}-\varepsilon_{\mathrm{i}} D_{\mathrm{dry}}^{3}\right)}-A_{\mathrm{FHH}}\left(\frac{D_{\mathrm{P}}-\varepsilon_{\mathrm{i}}^{\frac{1}{3}} D_{\mathrm{dry}}}{2 D_{\mathrm{w}}}\right)^{-B_{\mathrm{FHH}}},
$$

where $\varepsilon_{\mathrm{i}}$ is the insoluble volume fraction and $\varepsilon_{\mathrm{S}}$ is the soluble volume fraction. Equation (3) takes into account both the inherent hydrophilicity from adsorption expressed in the third term of the equation and the acquired hygroscopicity from soluble salts by dust particles expressed in the second term of the equation. The first term accounts for the Kelvin effect. Noting that for a complete insoluble dust particle, i.e., as $\varepsilon_{\mathrm{S}} \rightarrow 0$ and $\varepsilon_{\mathrm{i}} \rightarrow 1$, the UAF approaches FHH theory (Eq. 2). Black carbon (BC) is not expressed by the FHH terms in Eq. (3). Instead, BC is assumed to have zero hygroscopicity and affects $\kappa$ in Eq. (3) according to the simple mixing rule.

Calculation of CDNC is carried out in two conceptual steps, one involving the determination of the "CCN spectrum" (i.e., the number of $\mathrm{CCN}$ that can activate to form droplets at a certain level of supersaturation) and another one determining the maximum supersaturation, $s_{\max }$, that develops in the ascending cloudy air parcels used to represent droplet formation in EMAC. The CDNC is then the value of the CCN spectrum at $s_{\max }$.

The "CCN spectrum", $F^{\mathrm{s}}(s)$, is computed following $\mathrm{Ku}-$ mar et al. (2009b) and assumes that particles can be described either by KT or FHH theory. $F^{\mathrm{s}}(s)$ for an external mixture of lognormal particle size distributions is given by

$$
F^{\mathrm{s}}(s)=\int_{0}^{\mathrm{s}} n^{\mathrm{s}}(s) \mathrm{d} s=\sum_{i=1}^{n_{\mathrm{m}}} \frac{N_{i}}{2} \operatorname{erfc}\left[-\frac{\ln \left(\frac{s_{\mathrm{g}, i}}{s}\right)}{x \sqrt{2} \ln \left(\sigma_{i}\right)}\right],
$$

where $s$ is the level of water vapor supersaturation, $n^{\mathrm{s}}(s)$ is the critical supersaturation distribution, $s_{\mathrm{g}, i}$ is the critical supersaturation of the particle with a diameter equal to the geometric mean diameter of the mode $i, \sigma_{i}$ is the geometric standard deviation for the mode $i$, and $x$ is an exponent that depends on the activation theory used. For modes following Köhler theory, $x=-3 / 2$ (Fountoukis and Nenes, 2005), while for insoluble particles following FHH theory, $x$ depends on $A_{\mathrm{FHH}}$ and $B_{\mathrm{FHH}}$ (Kumar et al., 2009b) (i.e., $x=0.86$ for $A_{\mathrm{FHH}}=2.25$ and $B_{\mathrm{FHH}}=1.20$ used here). In the case of UAF, $x$ lies between the KT and FHH-AT limits, and is determined from Eq. (3) by performing a power law fit between $s_{\mathrm{g}}$ and $D_{\text {dry }}$ as described in Kumar et al. (2011a). 
The calculation of $s_{\mathrm{g}}$ involves determining the maximum of the relevant equilibrium curve in equilibrium with the surrounding water vapor $\left(\left.\frac{\mathrm{d} s}{\mathrm{~d} D_{\mathrm{p}}}\right|_{D_{\mathrm{p}}=D_{\mathrm{g}}}=0\right.$ in Eqs. 1-3). Once

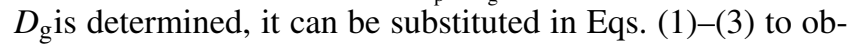
tain $s_{\mathrm{g}}$.

The maximum supersaturation, $s_{\max }$, in the ascending parcel is calculated from an equation that expresses the supersaturation tendency in cloudy air parcels, which at the point of maximum supersaturation becomes (Nenes and Seinfeld, 2003; Barahona and Nenes, 2007)

$\frac{2 a V}{\pi \gamma \rho_{\mathrm{w}}}-G s_{\max } I\left(0, s_{\max }\right)=0$,

where $V$ is the updraft velocity (i.e., not including convection) calculated online by assuming that the sub-grid vertical velocity variability is dominated by the turbulent transports and by choosing the root-mean-square value of the GCM model-generated turbulent kinetic energy (TKE) as a measure. Based on this assumption, the in-cloud updraft velocity can be expressed as $V=\bar{V}+0.7 \sqrt{\text { TKE}}$, where $\bar{V}$ is the GCM-resolved large-scale updraft velocity (Lohmann et al., 1999a, b). Following Morales and Nenes (2010), $V$ can be considered as a "characteristic updraft velocity" which yields a CDNC value representative of integration over a probability density function (PDF) of updraft velocity. Morales and Nenes (2010) have shown that this assumption applies well to large-scale clouds (i.e., stratocumulus), which are the type of clouds described by the CLOUD submodel in EMAC. $a$, $\gamma$, and $G$ in Eq. (5) are parameters defined in Nenes and Seinfeld (2003). $I\left(0, s_{\max }\right)$ is the "condensation integral" which expresses the condensational depletion of supersaturation upon the growing droplets at the point of $s_{\max }$ in the cloud updraft. It is expressed as the sum of two terms:

$I\left(0, s_{\max }\right)=I_{\mathrm{K}}\left(0, s_{\max }\right)+I_{\mathrm{FHH}}\left(0, s_{\max }\right)$.

The first term on the right-hand side of Eq. (6), $I_{\mathrm{K}}\left(0, s_{\max }\right)$, describes the contribution from particles that follow the Köhler theory and is calculated using the revisited population splitting approach of Morales Betancourt and Nenes (2014a). The second term, $I_{\mathrm{FHH}}\left(0, s_{\max }\right)$, represents the contribution of freshly emitted or aged dust particles to the condensation integral and is represented in Kumar et al. (2009b) and Karydis et al. (2011a). Once $s_{\max }$ is determined by numerically solving Eq. (5), the number of cloud droplets that form in the parcel, $N_{\mathrm{d}}$, is obtained from the "CCN spectrum" (Eq. 4) computed for $s_{\max }$, i.e., $N_{\mathrm{d}}=F\left(s_{\max }\right)$. The cloud droplet formation parameterization presented here has been extensively evaluated by comparing computations of $N_{\mathrm{d}}$ and $s_{\max }$ and their sensitivity to aerosol properties against detailed numerical simulations of the activation process by a parcel model (Morales Betancourt and Nenes, 2014a).

\subsection{Aerosol precursor emissions}

Dust emission fluxes are calculated online by an advanced dust flux scheme developed by Astitha et al. (2012). This scheme uses an explicit geographical representation of the airborne soil particle size distribution based on soil characteristics in every grid cell. Emissions of crustal species $\left(\mathrm{Ca}^{2+}, \mathrm{Mg}^{2+}, \mathrm{K}^{+}, \mathrm{Na}^{+}\right)$are estimated as a fraction of mineral dust emissions based on the chemical composition of the emitted soil particles in every grid cell (Karydis et al., 2016). Emissions of sea spray aerosols are based on the offline monthly emission dataset of AEROCOM (Dentener et al., 2006) assuming a composition of $55 \% \mathrm{Cl}^{-}, 30.6 \% \mathrm{Na}^{+}$, $7.7 \% \mathrm{SO}_{4}^{2-}, 3.7 \% \mathrm{Mg}^{2+}, 1.2 \% \mathrm{Ca}^{2+}$, and $1.1 \% \mathrm{~K}^{+}$(Seinfeld and Pandis, 2006). The CMIP5 RCP4.5 emission inventory (Clarke et al., 2007) is used for the anthropogenic primary organic aerosol emissions from fossil fuel and biofuel combustion sources. The open biomass burning emissions from savanna and forest fires are based on the GFED v3.1 database (van der Werf et al., 2010). More details about the aerosol-phase emissions used by EMAC can be found in Karydis et al. (2016) and Tsimpidi et al. (2016).

Related anthropogenic emissions of $\mathrm{NO}_{x}, \mathrm{NH}_{3}$, and $\mathrm{SO}_{2}$, which represent the gaseous precursors of the major inorganic components, are based on the monthly emission inventory of EDGAR-CIRCE (Doering et al., 2009) distributed vertically as presented in Pozzer et al. (2009). The natural emissions of $\mathrm{NH}_{3}$ are based on the GEIA database (Bouwman et al., 1997). $\mathrm{NO}_{x}$ produced by lightning is calculated online and distributed vertically based on the parameterization of Grewe et al. (2001). The emissions of NO from soils are calculated online based on the algorithm of Yienger and Levy (1995) as described in Ganzeveld et al. (2002). Eruptive and non-eruptive volcanic degassing emissions of $\mathrm{SO}_{2}$ are based on the AEROCOM dataset (Dentener et al., 2006). The oceanic DMS emissions are calculated online by the AIRSEA submodel (Pozzer et al., 2006). More details about the gas-phase emissions used by EMAC can be found in Pozzer et al. (2012) and Karydis et al. (2016).

\section{Model results and evaluation}

\subsection{Model predictions}

The annual and seasonal (during DJF and JJA) mean CDNC, calculated by EMAC with UAF implementation for the lowest model level at which clouds are formed (centered at $940 \mathrm{hPa}$ ), is shown in Fig. 1. In this study, CDNC refers to the number concentration of droplets nucleated in-cloud and represents an upper limit since droplet depletion by collision, coalescence and collection is not taken into account. Therefore, the calculated CDNC is mostly sensitive to the cloud updraft velocity and the total aerosol number concentration (Karydis et al., 2012), which are the main drivers of 

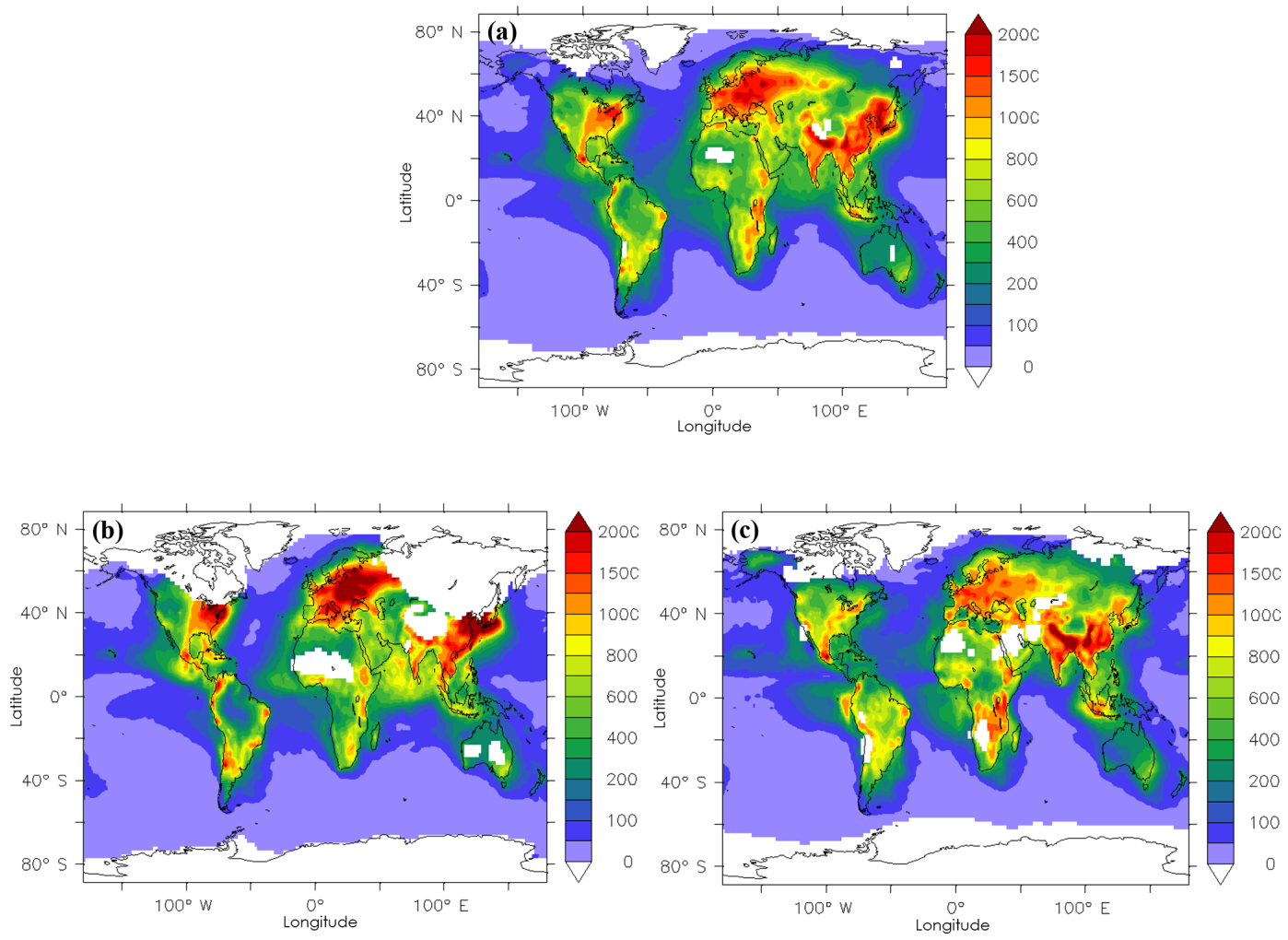

Figure 1. Predicted in-cloud (a) annual, (b) DJF, and (c) JJA mean cloud droplet number concentrations ( $\mathrm{cm}^{-3}$ ) at the lowest cloud-forming level $(940 \mathrm{hPa})$. White represents areas that are cloud-free or covered by ice clouds.

the $s_{\max }$ calculations. The annual mean aerosol number concentration, updraft velocity, and $s_{\max }$ at $940 \mathrm{hPa}$, as well as the low-level cloudiness calculated by EMAC, are shown in Fig. 2. The calculated CDNC is also sensitive to the fraction of mineral dust present in the aerosol since it can affect the aerosol-water vapor interactions by changing the exponent $x$ in Eq. (4). The annual mean insoluble fraction of the particles in the accumulation and coarse mode (where mineral dust exists) are shown in Fig. 3. The calculated global annual mean CDNC at $940 \mathrm{hPa}$ is $231 \mathrm{~cm}^{-3}$.

Over the continents, the predicted annual mean CDNC is $546 \mathrm{~cm}^{-3}$ and exceeds $1000 \mathrm{~cm}^{-3}$ over the industrialized areas of Europe, central and eastern Asia, and North America. In these areas, the aerosol number concentration is high (exceeding $10000 \mathrm{~cm}^{-3}$; Fig. 2a), while the calculated updraft velocities $\left(0.5-1 \mathrm{~m} \mathrm{~s}^{-1}\right.$; Fig. 2b) allow the development of sufficiently high $s_{\max }(0.1-0.3 \%$; Fig. 2c) for the activation of $5 \%$ (over eastern China) to $15 \%$ (over central Europe) of the pollution aerosols into cloud droplets. The simulated $s_{\max }$ is close to the estimated $s_{\max }(0.2-0.5 \%)$ for stratocumulus clouds based on data from continental air masses (Twomey and Wojciechowski, 1968; Martin et al., 1993), indicating that the combination of aerosol number concentration and updraft velocity in the model is realistic.

While the aerosol number concentration over the industrialized areas remains fairly constant throughout the year, the updraft velocity is higher during the boreal winter (i.e., DJF), resulting in a seasonal peak of CDNC during DJF (exceeding $2000 \mathrm{~cm}^{-3}$ ) over North America, Europe and eastern Asia (Fig. 1b). The highest annual mean CDNC is calculated over northern India $\left(\sim 2000 \mathrm{~cm}^{-3}\right)$, where the model simulates highest aerosol concentrations $\left(\sim 30000 \mathrm{~cm}^{-3}\right)$. Over Southeast Asia and India, CDNC peaks during JJA (exceeding $2000 \mathrm{~cm}^{-3}$; Fig. 1c), affected by the East Asian monsoon and the high updraft velocities developed during the wet season. Relatively high CDNC (annual mean of $300-700 \mathrm{~cm}^{-3}$ ) is also calculated over the tropical regions of the Southern Hemisphere which are influenced by biomass burning. Relatively low values are calculated over the Congo Basin, where the mean updraft velocity is typically low (below $0.2 \mathrm{~m} \mathrm{~s}^{-1}$ ) leading to low $s_{\max }$ (below $0.05 \%$ ) and cloud droplet activation $\left(\sim 300 \mathrm{~cm}^{-3}\right)$.

Downwind of deserts, the calculated CDNC varies between $100 \mathrm{~cm}^{-3}$ (e.g., Patagonia, and Australian deserts) and $1000 \mathrm{~cm}^{-3}$ (e.g., the Sahara and Arabian, Taklimakan, Gobi and Atacama deserts). In the vicinity of the Sahara and the Arabian Desert, the mean updraft velocity is $\sim 0.5 \mathrm{~m} \mathrm{~s}^{-1}$. However, downwind of the western part of the Sahara the aerosol number concentration is relatively low $\left(\sim 1000 \mathrm{~cm}^{-3}\right)$, leading to higher $s_{\max }(\sim 0.2 \%)$ but low CDNC $\left(\sim 200 \mathrm{~cm}^{-3}\right)$. On the other hand, downwind of the eastern Sahara and Arabian Desert the aerosol concentra- 

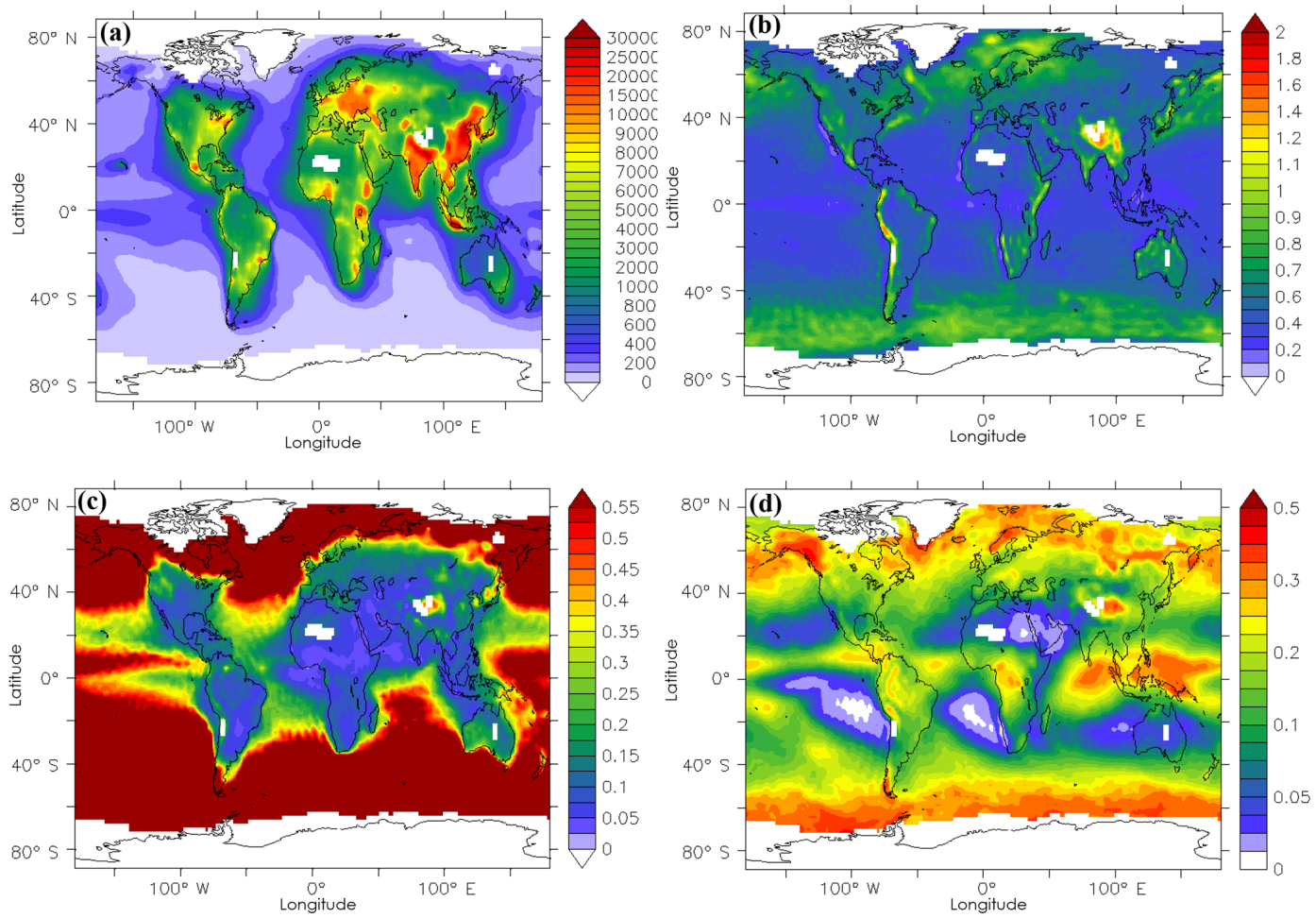

Figure 2. Predicted in-cloud annual mean (a) aerosol number concentration $\left(\mathrm{cm}^{-3}\right)$, (b) updraft velocity $\left(\mathrm{m} \mathrm{s}^{-1}\right)$, (c) maximum supersaturation $(\%)$ at the lowest cloud-forming level $(940 \mathrm{hPa})$, and (d) predicted annual mean low-level cloud cover. White areas correspond to regions where liquid cloud droplets do not form.
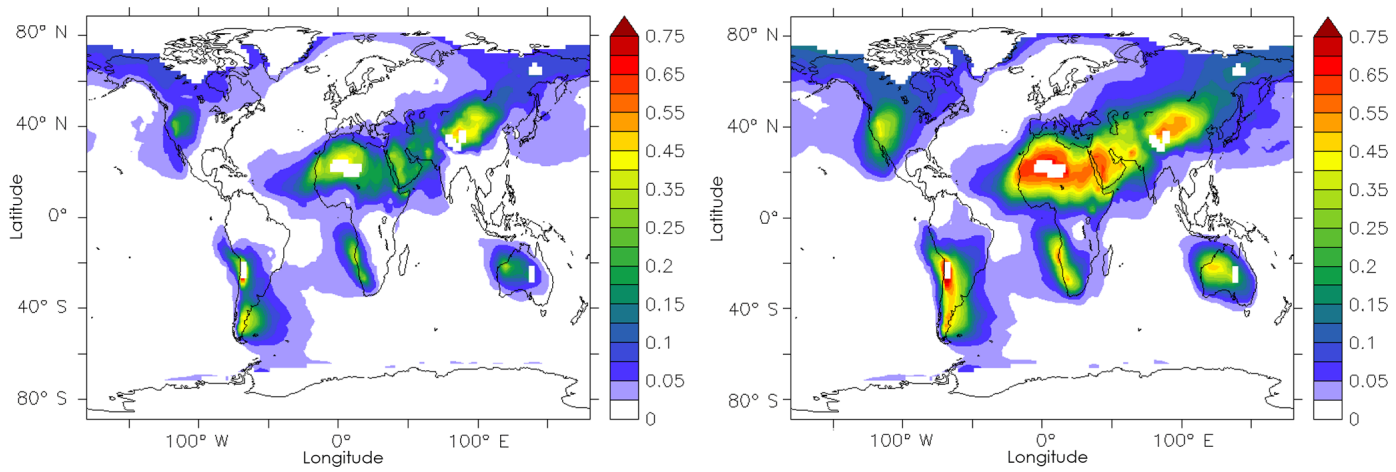

Figure 3. Predicted annual mean insoluble fraction of aerosols in the (a) accumulation and (b) coarse modes at the lowest cloud-forming level $(940 \mathrm{hPa})$.

tion is higher $\left(2000-3000 \mathrm{~cm}^{-3}\right)$. Over these areas the presence of a high number of coarse dust particles significantly reduces $s_{\max }(\sim 0.05 \%)$, but at the same time they efficiently activate into cloud droplets (CDNC varies from 500 to $\left.1000 \mathrm{~cm}^{-3}\right)$. Close to Patagonia and Australia, despite the high updraft velocities $\left(\sim 1 \mathrm{~m} \mathrm{~s}^{-1}\right)$, the aerosol concentration is low (below $500 \mathrm{~cm}^{-3}$ ) and also CDNC is relatively low $\left(\sim 100 \mathrm{~cm}^{-3}\right)$. The highest updraft velocities are calculated around the Atacama and Gobi deserts (over $1 \mathrm{~m} \mathrm{~s}^{-1}$ ) leading to both high $s_{\max }$ (over $0.3 \%$ ) and CDNC $\left(\sim 1000 \mathrm{~cm}^{-3}\right.$ ). However, the central Asian deserts (e.g., Gobi) are under the influence of the Siberian anticyclone during winter (i.e., DJF) which causes katabatic winds (that inhibit the formation of positive updraft velocities) and very low temperatures that prevent the formation of liquid water clouds.

Over the oceans, the predicted annual mean CDNC is $113 \mathrm{~cm}^{-3}$ and exceeds $500 \mathrm{~cm}^{-3}$ along the coasts of Mediterranean countries, China, India, Southeast Asia, California, the northeastern USA and western Africa (Fig. 1). Over many coastal regions aerosol concentrations are relatively high $\left(5000-10000 \mathrm{~cm}^{-3}\right)$, however, the low updraft velocities $\left(\sim 0.2 \mathrm{~m} \mathrm{~s}^{-1}\right)$ result in lower CDNC than over land 
(Fig. 1). The Mediterranean and Yellow seas are somewhat exceptional since the annual mean updraft velocities are higher in these regions $\left(\sim 0.3 \mathrm{~m} \mathrm{~s}^{-1}\right)$, resulting in higher $s_{\max }$ $(\sim 0.1$ and $\sim 0.3 \%$, respectively) and therefore high CDNC ( $\sim 800$ and $\sim 1200 \mathrm{~cm}^{-3}$, respectively). The simulated $s_{\max }$ is in close agreement with estimates $(\sim 0.1 \%)$ based on observational data over the eastern Mediterranean (Bougiatioti et al., 2016a; Kalkavouras et al., 2017). CDNC over these seas is subject to high seasonal variation ranging from $\sim 400 \mathrm{~cm}^{-3}\left(\sim 800 \mathrm{~cm}^{-3}\right)$ over the Mediterranean (Yellow) Sea during JJA to over $1000 \mathrm{~cm}^{-3}\left(2000 \mathrm{~cm}^{-3}\right)$ during DJF due to the higher updraft velocities during boreal winter (exceeding $1 \mathrm{~m} \mathrm{~s}^{-1}$ ) compared to summer (below $0.2 \mathrm{~m} \mathrm{~s}^{-1}$ ). Over the northern coasts, the annual mean CDNC is significantly enhanced compared to the oceans of the Southern Hemisphere due to the transport of pollutants from industrialized areas in the Northern Hemisphere. Despite the high updraft velocities calculated over the southern oceans throughout the year (up to $1 \mathrm{~m} \mathrm{~s}^{-1}$ ), the lack of aerosol (typically below $100 \mathrm{~cm}^{-3}$ ) results in CDNC below $50 \mathrm{~cm}^{-3}$. Finally, the calculated CDNC decreases with altitude due to the decrease in aerosol concentration by dilution and atmospheric removal (Fig. 4). The global mean CDNC is predicted to be $231,171,120,87$, and $60 \mathrm{~cm}^{-3}$ at $940,900,860,820$, and $770 \mathrm{hPa}$, respectively.

\subsection{Model evaluation}

The predicted in-cloud CDNC is compared to observational data from continental, polluted marine and clean marine regions around the world (Karydis et al., 2011a). The locations of observations (i.e., longitude, latitude, and altitude) and time of year have been taken into account in sampling the model results. Given that the observations span a decade, in contrast to the simulation which represents one year, the month of each campaign has been used to account for the seasonal variability in the CDNC. Thus, the implicit assumption is that inter-annual variability can be neglected. It should also be mentioned that the observations typically do not represent monthly means over $1.9^{\circ}$ grid squares, as sampled from the model results, so that the comparison is more qualitative than quantitative. Furthermore, the cloud-averaged CDNC for stratocumulus clouds, which are described by EMAC, is typically well captured by the cloud droplet formation parameterization used in this study (Meskhidze et al., 2005; Fountoukis et al., 2007; Morales et al., 2011), while the droplet collision and coalescence processes, which are neglected here, are becoming important only in the presence of clouds with substantial amount of drizzle. A summary of the comparison results is presented in Table 1 and Fig. 5. The mean bias (MB), mean absolute gross error (MAGE), normalized mean bias (NMB), normalized mean error (NME), and the root-mean-square error (RMSE) are used to assess the model performance (Table 2).

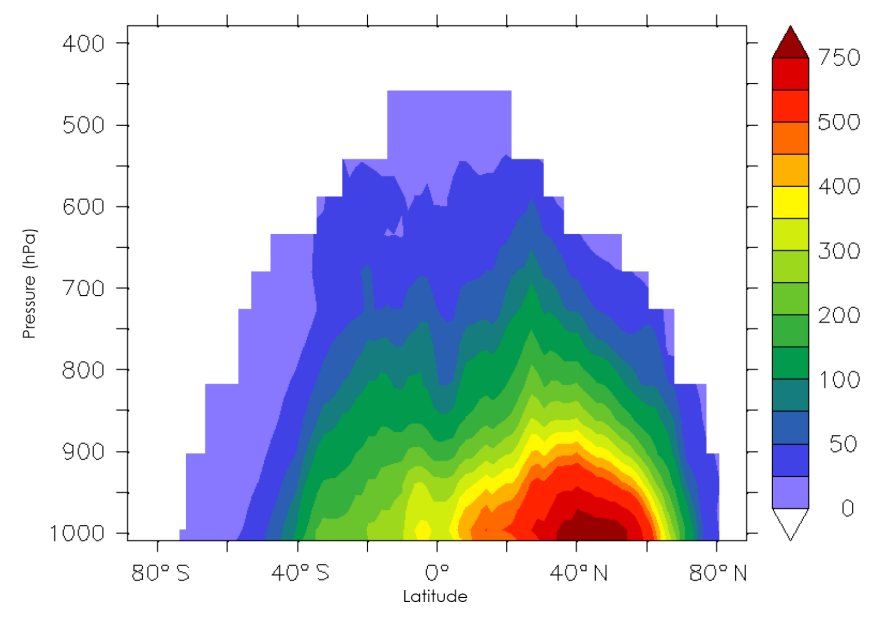

Figure 4. Predicted in-cloud zonal annual mean cloud droplet number concentration $\left(\mathrm{cm}^{-3}\right)$. White areas correspond to regions where liquid cloud droplets do not form.
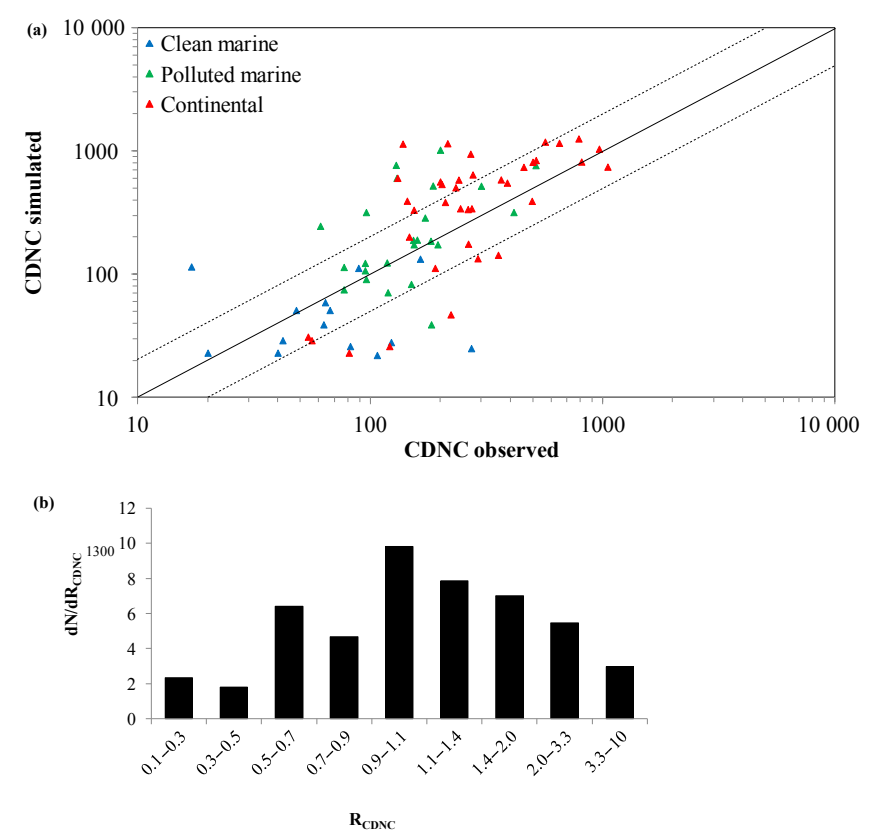

Figure 5. (a) Scatterplot comparing model simulated cloud droplet number concentrations $\left(\mathrm{cm}^{-3}\right)$ against 75 observational datasets worldwide, derived from in situ measurements and satellite retrievals, also shown are the $1: 1,2: 1,1: 2$ lines, and (b) the probability distribution of the ratio of the simulated CDNC to the observed CDNC $\left(R_{\mathrm{CDNC}}\right)$, where $N$ is the number of occurrences in each $R_{\mathrm{CDNC}}$.

The model captures the low values (below $100 \mathrm{~cm}^{-3}$ ) observed over the remote Pacific, Atlantic and Indian oceans and at the same time is capable of simulating the higher concentrations $\left(>100 \mathrm{~cm}^{-3}\right)$ observed over the eastern Pacific Ocean (Table 1). On the other hand, it falls short in reproducing the relatively high $\mathrm{CDNC}\left(>100 \mathrm{~cm}^{-3}\right)$ observed during 
Table 1. Comparison of simulated and observed (Karydis et al., 2011a, and references therein) cloud droplet number concentrations.

\begin{tabular}{|c|c|c|c|c|c|c|}
\hline Location & Lat. & Long. & Alt. & Time & Observation & Simulation \\
\hline S. Pacific Ocean & & & PBL & Annual & 40 & 23 \\
\hline S. Pacific Ocean & $20-35^{\circ} \mathrm{S}$ & $135-175^{\circ} \mathrm{W}$ & PBL & Annual & 82 & 26 \\
\hline Eastern Pacific Ocean & $29-32^{\circ} \mathrm{N}$ & $120-123^{\circ} \mathrm{W}$ & $450-850 \mathrm{~m}$ & July & $49-279$ & 133 \\
\hline N. Pacific Ocean & $41^{\circ} \mathrm{N}$ & $131^{\circ} \mathrm{W}$ & $<1500 \mathrm{~m}$ & April & $21-74$ & 51 \\
\hline N. Pacific Ocean & & & PBL & Annual & 64 & 59 \\
\hline W. of Canary Islands & $32^{\circ} \mathrm{N}$ & $25^{\circ} \mathrm{W}$ & PBL & July & 17 & 115 \\
\hline N. Atlantic Ocean & & & PBL & Annual & 89 & 112 \\
\hline S. Atlantic Ocean & & & PBL & Annual & 67 & 51 \\
\hline S. Indian Ocean & & & PBL & Annual & 42 & 29 \\
\hline West Australia (remote) & $30-40^{\circ} \mathrm{S}$ & $88-103^{\circ} \mathrm{E}$ & PBL & Annual & 107 & 22 \\
\hline Beaufort Sea (western Arctic Ocean) & $72-78^{\circ} \mathrm{N}$ & $154-159^{\circ} \mathrm{W}$ & $202-1017 \mathrm{~m}$ & June & $178-365$ & 25 \\
\hline Beaufort Sea (western Arctic Ocean) & $70.5-73^{\circ} \mathrm{N}$ & $145-147^{\circ} \mathrm{N}$ & $300-3000 \mathrm{~m}$ & June & $20-225$ & 28 \\
\hline Beaufort Sea (western Arctic Ocean) & $65-75^{\circ} \mathrm{N}$ & $130-170^{\circ} \mathrm{W}$ & $400-4600 \mathrm{~m}$ & April & $48-77$ & 39 \\
\hline Northeast Alaska coast & $69-71^{\circ} \mathrm{N}$ & $150-158^{\circ} \mathrm{W}$ & $400-4000 \mathrm{~m}$ & October & $10-30$ & 23 \\
\hline Yellow Sea (eastern coast of China) & $28-31^{\circ} \mathrm{N}$ & $127-131^{\circ} \mathrm{E}$ & PBL & Annual & $30-1000$ & 764 \\
\hline SE Asia coast & $10-40^{\circ} \mathrm{N}$ & $105-150^{\circ} \mathrm{E}$ & PBL & Annual & $186(100-250)$ & 522 \\
\hline NE Asia coast & & & PBL & Annual & 129 & 768 \\
\hline N. America coast (Pacific) & & & PBL & Annual & 96 & 91 \\
\hline N. America coast (Pacific) & $15-35^{\circ} \mathrm{N}$ & $115-140^{\circ} \mathrm{W}$ & PBL & Annual & $159(150-300)$ & 190 \\
\hline S. America coast (Pacific) & & & PBL & Annual & 77 & 75 \\
\hline S. America coast (Pacific) & $8-28^{\circ} \mathrm{S}$ & $70-90^{\circ} \mathrm{W}$ & PBL & Annual & $182(100-300)$ & 186 \\
\hline N. Africa coast (Atlantic) & & & PBL & Annual & 95 & 123 \\
\hline S. Africa coast (Atlantic) & & & PBL & Annual & 95 & 107 \\
\hline S. Africa coast (Atlantic) & $5-25^{\circ} \mathrm{S}$ & $10-15^{\circ} \mathrm{E}$ & PBL & Annual & $153(130-300)$ & 189 \\
\hline Eastern N. Atlantic Ocean & $50-55^{\circ} \mathrm{N}$ & $25-30^{\circ} \mathrm{W}$ & $800-2200 \mathrm{~m}$ & April & $65-300$ & 39 \\
\hline NW coast of Santa Maria, Azores & $37^{\circ} \mathrm{N}$ & $25^{\circ} \mathrm{W}$ & $550-1000 \mathrm{~m}$ & June & $150(74-192)$ & 83 \\
\hline Canary Islands Vicinity & $28^{\circ} \mathrm{N}$ & $16.5^{\circ} \mathrm{W}$ & PBL & June-July & $51-256$ & 174 \\
\hline Canary Islands Vicinity & $28^{\circ} \mathrm{N}$ & $16.5^{\circ} \mathrm{W}$ & PBL & June-July & $90-300$ & 174 \\
\hline Atlantic Ocean (W. of Morocco) & $34^{\circ} \mathrm{N}$ & $11^{\circ} \mathrm{W}$ & PBL & July & 77 & 114 \\
\hline Coast of Oregon & $45.5^{\circ} \mathrm{N}$ & $124.5^{\circ} \mathrm{W}$ & PBL & August & $25-210$ & 124 \\
\hline Key West, FL & $24.5^{\circ} \mathrm{N}$ & $82^{\circ} \mathrm{W}$ & PBL & July & $268-560$ & 318 \\
\hline Bay of Fundy, Nova Scotia, Canada & $44^{\circ} \mathrm{N}$ & $66^{\circ} \mathrm{W}$ & $20-290 \mathrm{~m}$ & August & $61(59-97)$ & 246 \\
\hline Cornwall Coast (SW UK) & $50^{\circ} \mathrm{N}$ & $5.5^{\circ} \mathrm{W}$ & $450-800 \mathrm{~m}$ & February & 130 & 602 \\
\hline British Isles, UK & $55^{\circ} \mathrm{N}$ & $2.5^{\circ} \mathrm{W}$ & Surface & April & 172 & 287 \\
\hline British Isles, UK & $51^{\circ} \mathrm{N}$ & $6^{\circ} \mathrm{W}$ & Surface & October & 119 & 71 \\
\hline British Isles, UK & $53^{\circ} \mathrm{N}$ & $9.5^{\circ} \mathrm{W}$ & Surface & December & 96 & 318 \\
\hline SE coast of England & $51.5-52^{\circ} \mathrm{N}$ & $1.5-2.5^{\circ} \mathrm{E}$ & $380-750 \mathrm{~m}$ & September & $151-249$ & 1019 \\
\hline Indian Ocean (SW of India) & $10-10^{\circ} \mathrm{N}$ & $65-75^{\circ} \mathrm{E}$ & $50-550 \mathrm{~m}$ & February-March & $100-500$ & 520 \\
\hline Qinghai Province (western China) & $34-37^{\circ} \mathrm{N}$ & $98-103^{\circ} \mathrm{E}$ & PBL & Annual & $30-700$ & 585 \\
\hline Beijing, China & $37-41^{\circ} \mathrm{N}$ & $113-120^{\circ} \mathrm{E}$ & PBL & Annual & $30-1100$ & 1185 \\
\hline NE China (east of Beijing) & $39-40^{\circ} \mathrm{N}$ & $117.5-118.5^{\circ} \mathrm{E}$ & $1719-1931 \mathrm{~m}$ & April-May & $200-800$ & 813 \\
\hline Hebei Province (central eastern China) & $35-40^{\circ} \mathrm{N}$ & $112-119^{\circ} \mathrm{E}$ & PBL & Annual & $30-400$ & 1150 \\
\hline Cumbria, N. England & $54.5^{\circ} \mathrm{N}$ & $2.5^{\circ} \mathrm{W}$ & Surface & March-April & $100-2000$ & 743 \\
\hline Cumbria, N. England & $54.5^{\circ} \mathrm{N}$ & $2.5^{\circ} \mathrm{W}$ & Surface & May & $482-549$ & 840 \\
\hline Koblenz, Germany & $50^{\circ} \mathrm{N}$ & $7.5^{\circ} \mathrm{E}$ & $901-914 \mathrm{hPa}$ & May & $675-900$ & 1258 \\
\hline Koblenz, Germany & $50^{\circ} \mathrm{N}$ & $7.5^{\circ} \mathrm{E}$ & $945 \mathrm{hPa}$ & October & 965 & 1039 \\
\hline Northern Finland & $68^{\circ} \mathrm{N}$ & $24^{\circ} \mathrm{E}$ & $342-572 \mathrm{~m}$ & Annual & $154(30-610)$ & 332 \\
\hline Kuopio, Finland & $62.5^{\circ} \mathrm{N}$ & $27.5^{\circ} \mathrm{E}$ & $306 \mathrm{~m}$ & August-November & 138 & 1142 \\
\hline Northern Finland & $68^{\circ} \mathrm{N}$ & $24^{\circ} \mathrm{E}$ & $342-572 \mathrm{~m}$ & October-November & $55-470$ & 336 \\
\hline Cabauw, Netherland & $51^{\circ} \mathrm{N}$ & $4.5^{\circ} \mathrm{E}$ & PBL & May & $180-360$ & 946 \\
\hline Jungfraujoch, Switzerland & $46.5^{\circ} \mathrm{N}$ & $7.5^{\circ} \mathrm{E}$ & Surface & July-August & $112-416$ & 176 \\
\hline Barrow, AK & $71.5^{\circ} \mathrm{N}$ & $156.5^{\circ} \mathrm{W}$ & $389-830 \mathrm{~m}$ & August & 56 & 47 \\
\hline Barrow, AK & $71.5^{\circ} \mathrm{N}$ & $156.5^{\circ} \mathrm{W}$ & $431-736 m$ & May & 222 & 26 \\
\hline Barrow, AK & $71.5^{\circ} \mathrm{N}$ & $156.5^{\circ} \mathrm{W}$ & $297-591 \mathrm{~m}$ & June & 121 & 31 \\
\hline Barrow, AK & $71.5^{\circ} \mathrm{N}$ & $156.5^{\circ} \mathrm{W}$ & $393-762 \mathrm{~m}$ & July & 54 & 29 \\
\hline Barrow, AK & $71.5^{\circ} \mathrm{N}$ & $156.5^{\circ} \mathrm{W}$ & $1059-1608 \mathrm{~m}$ & September & 81 & 23 \\
\hline Southern Great Plains, OK & $36.5^{\circ} \mathrm{N}$ & $97.5^{\circ} \mathrm{W}$ & $795-1450 \mathrm{~m}$ & Winter & $265-281$ & 341 \\
\hline Southern Great Plains, OK & $36.5^{\circ} \mathrm{N}$ & $97.5^{\circ} \mathrm{W}$ & $343-1241 \mathrm{~m}$ & Winter & 244 & 341 \\
\hline Southern Great Plains, OK & $36.5^{\circ} \mathrm{N}$ & $97.5^{\circ} \mathrm{W}$ & $985-1885 \mathrm{~m}$ & Spring & $200-219$ & 384 \\
\hline Southern Great Plains, OK & $36.5^{\circ} \mathrm{N}$ & $97.5^{\circ} \mathrm{W}$ & $671-1475 \mathrm{~m}$ & Spring & 203 & 537 \\
\hline
\end{tabular}


Table 1. Continued.

\begin{tabular}{|c|c|c|c|c|c|c|}
\hline Location & Lat. & Long. & Alt. & Time & Observation & Simulation \\
\hline Southern Great Plains, OK & $36.5^{\circ} \mathrm{N}$ & $97.5^{\circ} \mathrm{W}$ & $1280-2200 \mathrm{~m}$ & Summer & $128-159$ & 393 \\
\hline Southern Great Plains, OK & $36.5^{\circ} \mathrm{N}$ & $97.5^{\circ} \mathrm{W}$ & $756-1751 \mathrm{~m}$ & Summer & 131 & 603 \\
\hline Southern Great Plains, OK & $36.5^{\circ} \mathrm{N}$ & $97.5^{\circ} \mathrm{W}$ & $1030-1770 \mathrm{~m}$ & Autumn & $217-249$ & 505 \\
\hline Southern Great Plains, OK & $36.5^{\circ} \mathrm{N}$ & $97.5^{\circ} \mathrm{W}$ & $404-1183 \mathrm{~m}$ & Autumn & 276 & 642 \\
\hline Southern Great Plains, OK & $36.5^{\circ} \mathrm{N}$ & $97.5^{\circ} \mathrm{W}$ & $900-800 \mathrm{hPa}$ & March & $200(100-320)$ & 563 \\
\hline Southern Great Plains, OK & $36.5^{\circ} \mathrm{N}$ & $97.5^{\circ} \mathrm{W}$ & $300-600 \mathrm{~m}$ & April & 650 & 1159 \\
\hline Southern Great Plains, OK & $36.5^{\circ} \mathrm{N}$ & $97.5^{\circ} \mathrm{W}$ & $700-1200 \mathrm{~m}$ & September-October & 457 & 740 \\
\hline Cleveland, OH; Detroit, MI & $40-42.5^{\circ} \mathrm{N}$ & $80.5-85^{\circ} \mathrm{W}$ & $300-1000 \mathrm{~m}$ & August & $320-1300$ & 817 \\
\hline Central Ontario, Canada & $50^{\circ} \mathrm{N}$ & $85^{\circ} \mathrm{W}$ & $<2500 \mathrm{~m}$ & October & $147(119-173)$ & 201 \\
\hline Central Ontario, Canada & $50^{\circ} \mathrm{N}$ & $85^{\circ} \mathrm{W}$ & $2000-2100 \mathrm{~m}$ & Summer & $350-360$ & 143 \\
\hline Central Ontario, Canada & $50^{\circ} \mathrm{N}$ & $85^{\circ} \mathrm{W}$ & $1300 \mathrm{~m}$ & Winter & 190 & 112 \\
\hline Upper NY State & $44^{\circ} \mathrm{N}$ & $75^{\circ} \mathrm{W}$ & $1500 \mathrm{~m}$ & Autumn & 240 & 583 \\
\hline State College, PA & $41^{\circ} \mathrm{N}$ & $78^{\circ} \mathrm{W}$ & $1000-1600 \mathrm{~m}$ & October & 388 & 551 \\
\hline Mount Gibbes, NC & $35.5^{\circ} \mathrm{N}$ & $82^{\circ} \mathrm{W}$ & Surface & Annual & $238-754$ & 392 \\
\hline Cape Kennedy, FL & $28.5^{\circ} \mathrm{N}$ & $80.5^{\circ} \mathrm{W}$ & $600-2800 \mathrm{~m}$ & August & $250-330$ & 134 \\
\hline
\end{tabular}

Table 2. Statistical evaluation of EMAC CDNC against 75 observational datasets worldwide, derived from in situ measurements and satellite retrievals.

\begin{tabular}{lrrrrrrrr}
\hline Site type & $\begin{array}{r}\text { Number of } \\
\text { datasets }\end{array}$ & $\begin{array}{r}\text { Mean observed } \\
\left(\mathrm{cm}^{-3}\right)\end{array}$ & $\begin{array}{r}\text { Mean simulated } \\
\left(\mathrm{cm}^{-3}\right)\end{array}$ & $\begin{array}{r}\text { MAGE } \\
\left(\mathrm{cm}^{-3}\right)\end{array}$ & $\begin{array}{r}\text { MB } \\
\left(\mathrm{cm}^{-3}\right)\end{array}$ & $\begin{array}{r}\text { NME } \\
(\%)\end{array}$ & $\begin{array}{r}\text { NMB } \\
(\%)\end{array}$ & $\begin{array}{r}\text { RMSE } \\
\left(\mathrm{cm}^{-3}\right)\end{array}$ \\
\hline Clean marine & 14 & 86 & 53 & 51 & -33 & 60 & -39 & 81 \\
Polluted marine & 24 & 169 & 296 & 159 & 127 & 94 & 75 & 263 \\
Continental & 37 & 339 & 536 & 269 & 198 & 80 & 58 & 358 \\
\hline Total & 75 & 237 & 369 & 193 & 132 & 82 & 56 & 295 \\
\hline
\end{tabular}

summer over the western Arctic Ocean and over the remote area west of Australia. Overall, the model tends to underestimate the CDNC over remote oceans with a $\mathrm{MB}=-33 \mathrm{~cm}^{-3}$ and $\mathrm{NMB}=-39 \%$ (Table 2 ).

Both the observed and simulated CDNC shows significant increases over polluted marine regions close to the coasts (Table 1; Fig. 5a). Compared to satellite retrievals (Bennartz, 2007; Rausch et al., 2010), the model reproduces the CDNC over the American and African coasts well, but it significantly overestimates CDNC along the Asian coasts (Table 1). Compared to in situ observations, the model reproduces the high CDNC along coastal areas in the Northern Hemisphere (e.g., the Yellow Sea, Oregon, Florida, Canary Islands) but systematically overestimates CDNC over the British coasts. Further, the model does not reproduce some of the high CDNC observations over more remote areas (i.e., over the Azores and eastern Atlantic Ocean). Overall, the model tends to overestimate the CDNC over polluted marine areas, with $\mathrm{MB}=127 \mathrm{~cm}^{-3}$ and $\mathrm{NMB}=75 \%$ (Table 2).

The observed CDNC over continental regions is subject to high spatial variability, with reported values ranging from $<100 \mathrm{~cm}^{-3}$ over Alaska (Dong and Mace, 2003) to $>1000 \mathrm{~cm}^{-3}$ over China (Zhao et al., 2006), England (Bower et al., 1999), and the continental USA (Fountoukis et al., 2007). The model captures the observed variabil- ity with low values over remote areas (e.g., over Alaska) and high values over the industrialized parts of the Northern Hemisphere (i.e., East Asia, Europe, and China). Overall, the model overestimates CDNC over continental regions $\left(\mathrm{MB}=269 \mathrm{~cm}^{-3}\right.$ and $\mathrm{NMB}=58 \%$; Table 2). Over China, the simulated CDNC is within the observed range with the exception of Hebei Province, where it significantly overestimates measured CDNC (Table 1). In Europe, the model reproduces the high CDNC observed over Central Europe and England but it clearly overestimates the low CDNC values observed over Finland. Over North America, the model captures the variability in the observed CDNC, predicting lower values over remote areas (e.g., Alaska) and higher values over the industrialized areas of USA (e.g., Ohio and Michigan). It tends to overestimate the CDNC over the continental USA and underestimate the observed values over Alaska.

Globally, the calculated NMB is $56 \%$ and the NME is $82 \%$, indicating that some of the discrepancy between the modeled and the observed CDNC is explained by uncertainties in the observations and the numerical simulations. Around $60 \%$ of the simulated CDNC is within a factor of 2 compared to the measurements (Fig. 5a) and $40 \%$ of the simulated CDNC differs less than $30 \%$ from the measurements. Based on the typical properties of marine stratus clouds, a uniform increase in global CDNC by $30 \%$ (or $50 \%$ ) leads 

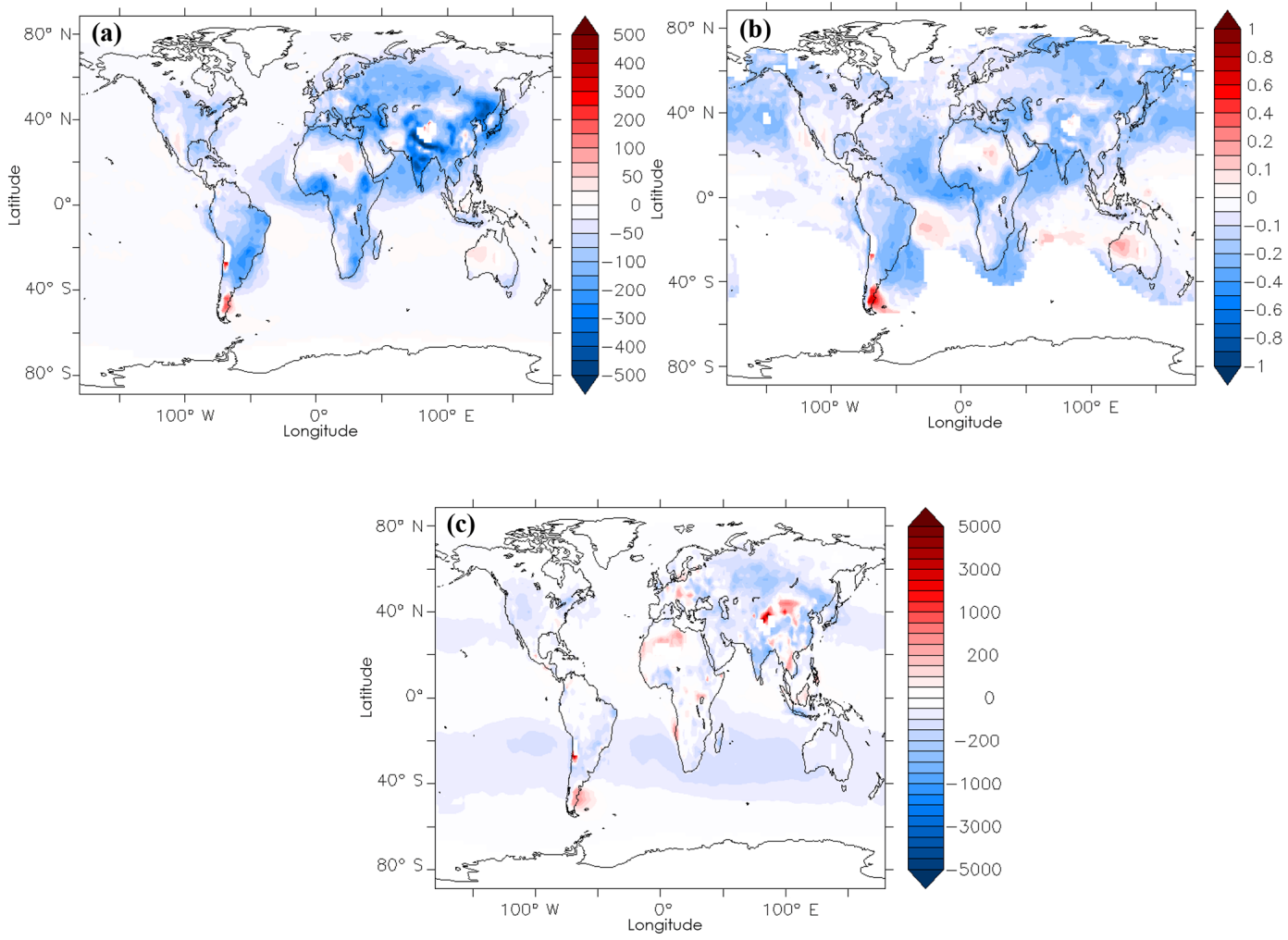

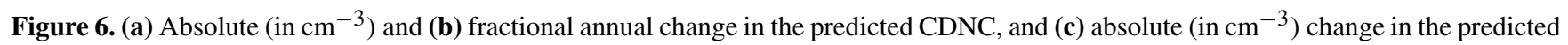
aerosol number concentration (at the lowest cloud-forming level, $940 \mathrm{hPa}$ ) by switching on/off the mineral dust emissions. A positive change corresponds to an increase from the presence of dust.

to an increase in cloud albedo of $2.25 \%$ (or $3.75 \%$ ) and a perturbation of $-1.1 \mathrm{~W} \mathrm{~m}^{-2}$ (or $-1.7 \mathrm{~W} \mathrm{~m}^{-2}$ ) in the global mean cloud radiative forcing (Schwartz, 1996). However, the simulated CDNC presented here refers to the number concentration of droplets nucleated in clouds and represents an upper limit with respect to the comparison with observations, since collision and coalescence processes, which are not taken into account here, can reduce the CDNC.

\section{Mineral dust effect on CDNC}

\subsection{Total impact of mineral dust on CDNC}

To estimate the overall effect of mineral dust on CDNC a sensitivity run was conducted switching off the mineral dust emissions. Figure 6 depicts the difference in CDNC between the base case simulation and the sensitivity test. A positive change corresponds to an increase in the CDNC due to the presence of dust. The predicted CDNC is typically increased by the presence of dust aerosols over the main deserts (Fig. 6). Over the Sahara, CDNC increases less than $50 \mathrm{~cm}^{-3}$ (up to $20 \%$ ). The largest change is calculated downwind of the Patagonian $\left(\sim 150 \mathrm{~cm}^{-3}\right.$ or $\left.70 \%\right)$ and Atacama $\left(\sim 350 \mathrm{~cm}^{-3}\right.$ or $\left.40 \%\right)$ deserts. Over these deserts dust emissions increase the aerosol concentration by more than $5000 \mathrm{~cm}^{-3}$ (Fig. 6c). The effect of mineral dust on CDNC close to Sahara varies significantly throughout the year due to the seasonality of the mineral dust emissions. Over the subSahelian region, CDNC increases by up to $150 \mathrm{~cm}^{-3}$ during DJF, owing to the northeasterly trade winds (i.e., Harmattan winds) which blow from the Sahara over West Africa during winter. Over the eastern Sahara and the Arabian deserts CDNC increases up to $150 \mathrm{~cm}^{-3}$ during spring (i.e., MAM) and autumn (i.e., SON) when the Sirocco winds are most common.

In contrast to regions close to deserts, CDNC decreases over the polluted regions of the Northern Hemisphere and especially over southern Europe $(\sim 100$ or less than $10 \%)$ and northeastern Asia (up to $400 \mathrm{~cm}^{-3}$ or $20 \%$ ). In these areas, dust particles transported from the Sahara over $\mathrm{Eu}$ rope and from the Gobi and Taklimakan deserts over Asia are mixed with anthropogenic particles decreasing the total aerosol number concentration (Fig. 6c), due to coagulation, and affecting the aerosol-water vapor interactions. As the insoluble fraction of aerosols increases due to the addition of mineral dust (Fig. 3b and c), the exponent $x$ in Eq. (4) changes, resulting in a decrease in the number of activated droplets. Furthermore, the relatively large, aged dust particles over these areas activate early on in the cloud formation 
process, taking up much water per particle and thus reducing $s_{\max }(\sim 15 \%)$ and, consequently, cloud droplet formation on the smaller anthropogenic particles (e.g., the activated fraction of the particles in the accumulation mode reduces by $20 \%$ ). Besides microphysical effects, the presence of mineral dust can also affect cloud formation by altering the energy balance of the atmosphere, and thus turbulent motions and the updraft velocity.

Nevertheless, the calculated updraft velocity does not change significantly between the two simulations (less than $5 \%$ ), in part because the meteorology is dynamically nudged to analysis data (Jeuken et al., 1996). CDNC also decreases over the oceans downwind of deserts in the Northern Hemisphere, and even over the rainforests in the Southern Hemisphere $(\sim 150$ or $30 \%)$. Overall, the impact of mineral dust on CDNC is positive only in areas with low cloud cover (i.e., over the main deserts where cloud cover is typically lower than 5\%; Fig. 2d). On the other hand, mineral dust negatively affects cloud droplet formation over areas with high cloud cover (e.g., over Europe and eastern Asia). Despite CDNC increasing over the deserts due to the presence of dust particles, the decrease in CDNC over the industrialized and forested continental areas dominates the calculated global average change - i.e., the calculated global average CDNC decreases by $11 \%$ (or $26 \mathrm{~cm}^{-3}$ ).

\subsection{Impact of mineral dust chemistry on CDNC}

To estimate the effects of thermodynamic mineral dust interactions with inorganic anions on the predicted CDNC, a sensitivity run was conducted by switching off the dustaerosol chemistry. Karydis et al. (2016) have shown that dust can significantly affect the partitioning of inorganic aerosol components and especially nitrate. Analogous to Karydis et al. (2016), accounting for thermodynamic interactions of mineral dust in our simulations results in an increase in the tropospheric burden of nitrate, chloride, and sulfate aerosols by 44,9 , and $7 \%$, respectively. On the other hand, ammonium decreases by $41 \%$. The dust presence itself also decreases by $14 \%$ since it becomes significantly more soluble, mostly due to the condensation of nitric acid on its surface, and is removed more efficiently through wet and dry deposition, the latter partially due to the increased sedimentation by dust particles that have a larger water content. Therefore, the calculated change in CDNC (Fig. 7a and b) is the net result of counterbalancing effects. Due to the increase in the soluble fraction by considering mineral dust chemistry, the CDNC activated from dust particles increases (Fig. 7c), while the total number of dust particles and the CDNC from insoluble particles decreases (Fig. 7d). Taking a grid cell over the Sahara as an example, the model simulations indicate that by accounting for the mineral dust chemistry, the soluble fraction of the dust containing particles increases by 0.07 , resulting in an increase in CDNC activated from soluble aerosol modes by $150 \mathrm{~cm}^{-3}$ (Fig. 7c). On the other hand, the aerosol number concentration decreases by $90 \mathrm{~cm}^{-3}$ due to the more efficient atmospheric removal of the aged dust particles, resulting in a decrease in the CDNC activated from the insoluble modes by $50 \mathrm{~cm}^{-3}$ (Fig. 7d). The net effect is that the total CDNC increases by $100 \mathrm{~cm}^{-3}$ (Fig. 7a).

Overall, the presence of reactive dust components results in an increase in CDNC over the deserts that are close to anthropogenic sources, e.g., up to $100 \mathrm{~cm}^{-3}$ (or $20 \%$ ) over the Sahara and up to $200 \mathrm{~cm}^{-3}$ (or $30 \%$ ) over the Arabian Peninsula. In these areas, the CCN activity of mineral dust (initially hydrophilic) is enhanced by the acquired hygroscopicity from the anthropogenic (including biomass burning) aerosol compounds (mainly nitrate). Even though the chemically aged dust particles activate into droplets more efficiently than insoluble ones, their reduced number concentration dominates the calculated effect on CDNC over the relatively pristine remote desert regions; for example, CDNC decreases up to $200 \mathrm{~cm}^{-3}$ (or $20 \%$ ) downwind of the Taklimakan, $250 \mathrm{~cm}^{-3}$ (or $30 \%$ ) around the Atacama, and up to $100 \mathrm{~cm}^{-3}$ (or $40 \%$ ) over the Patagonian deserts. Even over the rainforests, $\mathrm{HNO}_{3}$ from $\mathrm{NO}_{x}$, emitted by biomass burning, thermodynamically interacts with the coarse soil particles from the upwind deserts, resulting in an increase in CDNC by around $50 \mathrm{~cm}^{-3}$. CDNC is also slightly increased over Europe and eastern Asia (up to $150 \mathrm{~cm}^{-3}$ or about $10 \%$ ), where $\mathrm{HNO}_{3}$ from anthropogenic $\mathrm{NO}_{x}$ sources interacts with mineral dust from the surrounding deserts. While the global average CDNC does not change much by taking into account thermodynamic and chemical interactions of mineral dust with inorganic air pollutants, CDNC spatial distributions change substantially.

\subsection{Impact of water adsorption by mineral dust on CDNC}

To estimate the effects of water adsorption onto the surface of insoluble dust particles on CDNC, a sensitivity run was conducted by switching off the FHH adsorption calculations. In this sensitivity simulation, the soluble modes follow the $\kappa$-Köhler theory, while insoluble modes do not participate in cloud droplet formation calculations. Figure 8 depicts the difference in CDNC between the base case simulation and this sensitivity test. A positive change corresponds to an increase in the CDNC from water adsorption on mineral dust. The calculations show that CDNC is increased by applying FHH theory over several arid areas where the insoluble dust concentration is high (Fig. 8), since $\kappa$-Köhler theory does not take into account the contribution of insoluble particles to cloud droplet formation. CDNC is increased in the vicinity of the Sahara and the Arabian and Thar deserts $\left(\sim 100 \mathrm{~cm}^{-3}\right.$ or about $+20 \%$ ), where the insoluble fraction of mineral dust is larger due to the small anthropogenic emission influence that makes the particles hygroscopic. On the other hand, CDNC decreases over the polluted regions of the Northern Hemisphere and especially over Europe $\left(\sim 100 \mathrm{~cm}^{-3}\right.$ or about 

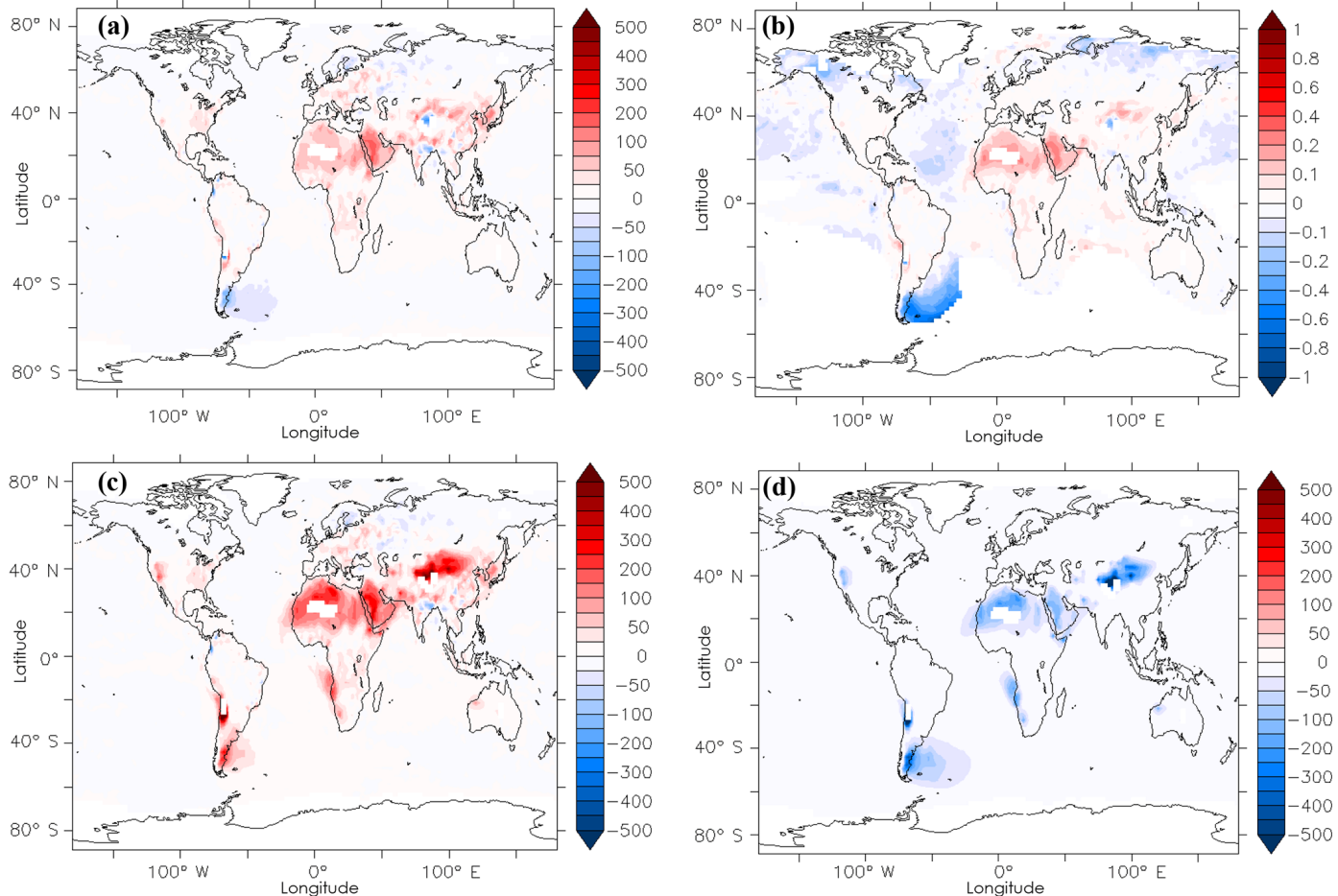

Figure 7. (a) Absolute (in $\mathrm{cm}^{-3}$ ) and (b) fractional annual average change in the predicted total CDNC, and absolute (in $\mathrm{cm}^{-3}$ ) annual average change in the CDNC from (c) soluble, and (d) insoluble particle modes, by switching on/off the mineral dust chemistry. Concentrations reported at the lowest cloud-forming level $(940 \mathrm{hPa})$. A positive change corresponds to an increase from dust-chemistry interactions.
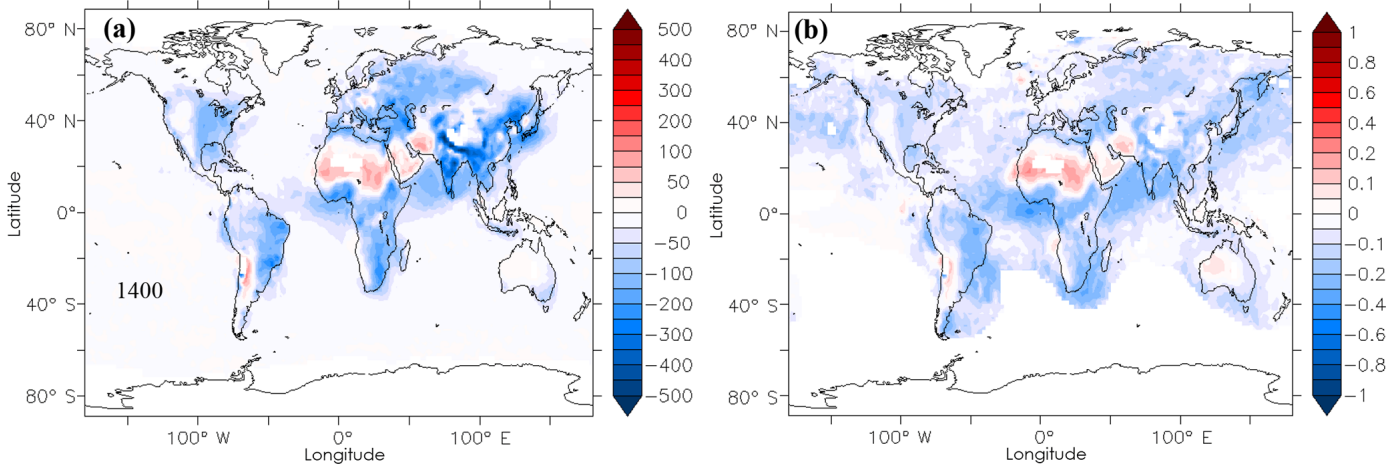

Figure 8. (a) Absolute (in $\mathrm{cm}^{-3}$ ) and (b) fractional annual average change in the predicted CDNC (at the lowest cloud-forming level, $940 \mathrm{hPa}$ ) by switching on/off the FHH adsorption activation physics. A positive change corresponds to an increase from water adsorption on mineral dust.

$-10 \%$ ) and Asia (up to $\sim 400 \mathrm{~cm}^{-3}$ or $-20 \%$ ). Over these areas, the added hydrophilicity by the soluble coatings on the surface of the aged dust particles increases their water uptake during activation. Therefore, the aged dust particles relatively strongly compete for water vapor, reducing the $s_{\max }$ $(\sim 15 \%)$ and thus cloud droplet formation from the smaller anthropogenic particles. Over the tropical rainforests CDNC decreases by $\sim 150 \mathrm{~cm}^{-3}$ (about $-30 \%$ ). Overall, the use of the UAF results in a decrease in the global average CDNC by $\sim 10 \%$ (or about $-23 \mathrm{~cm}^{-3}$ ).

\section{Additional sensitivity tests}

Three additional sensitivity simulations were conducted to investigate the CDNC dependency on (i) the chemical composition of the emitted dust aerosols, (ii) the hydrophilicity of mineral dust, and (iii) the strength of the dust aerosol emissions. Figure 9 depicts the absolute annual mean changes in CDNC compared to the reference simulation for each of the sensitivity tests. A positive change corresponds to an increase in the $\mathrm{CDNC}$ relative to the reference. 

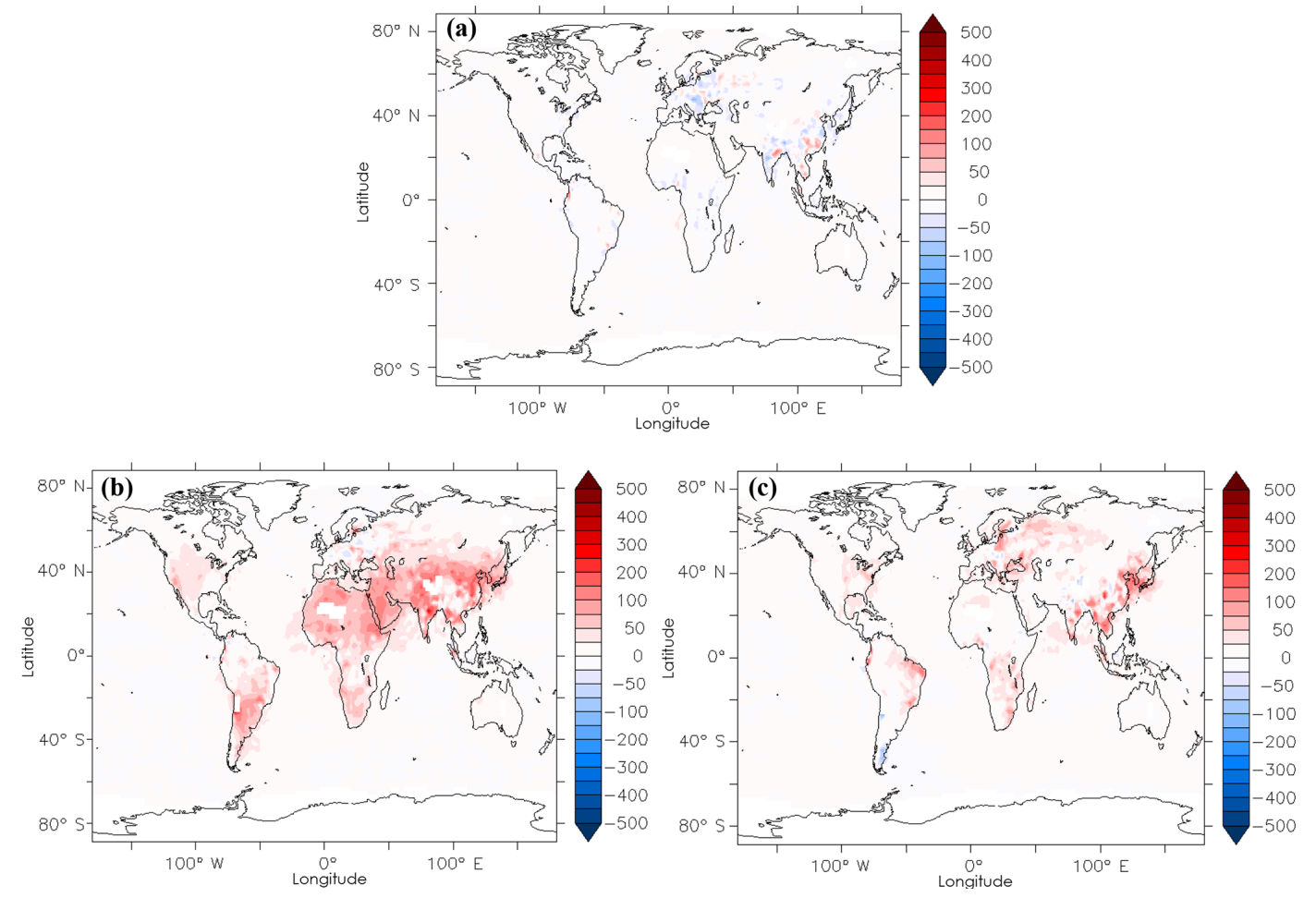

Figure 9. Absolute changes (in $\mathrm{cm}^{-3}$ ) of the predicted annual average CDNC by (a) assuming a globally uniform chemical composition of mineral dust, (b) increasing the $B_{\mathrm{FHH}}$ hydrophilicity parameter of dust by $10 \%$, and (c) reducing mineral dust emissions by $50 \%$. A positive change corresponds to an increase relative to the reference simulation.

\subsection{Sensitivity to the emitted dust aerosol composition}

The first sensitivity test assumes a globally uniform chemical composition of mineral dust (Sposito, 1989), in contrast to the reference simulation where the mineral dust composition depends on the soil characteristics of each desert (Karydis et al., 2016). While the emitted mineral dust load remains the same in the sensitivity simulation, the different mineral dust composition results in significant changes in the calculated tropospheric burdens of dust components (Karydis et al., 2016). In particular, the fraction of the mineral components relative to the total dust in the sensitivity simulation is lower over most of the deserts compared to the reference. This reduction of the chemically reactive mineral components in the sensitivity simulation results in a slowdown of the mineral dust aging and hence in an increase in its concentration due to the reduced atmospheric removal. Conversely, the CCN activity of dust particles is higher in the reference simulation since the chemical aging is more efficient compared to the sensitivity simulation. These counterbalancing effects result in negligible changes of CDNC worldwide (less than $10 \%$ ).

\subsection{Sensitivity to the hydrophilicity of dust}

The second sensitivity test assumes increased hydrophilicity of mineral dust aerosols by using a $10 \%$ lower $B_{\mathrm{FHH}}$ parameter $\left(B_{\mathrm{FHH}}=1.1\right)$. The $B_{\mathrm{FHH}}$ parameter directly affects the CCN activity of dust particles by changing the equilibrium supersaturation (Eq. 3 ) and the "CCN spectrum" (Eq. 4) through the exponent $x$. Kumar et al. (2011b) tested the $\mathrm{CCN}$ activity of aerosols dry generated from clays, calcite, quartz, and desert soil samples from northern Africa, East Asia/China, and North America. They found that $B_{\mathrm{FHH}}$, which strongly affects the equilibrium curve, varied from 1.12 to 1.30 (i.e., $\pm 10 \%$ from 1.2 , which is the value used in our base case simulation). Therefore, the sensitivity test presented here can represent the potential impacts on the results due the simplification of using a globally uniform set of FHH parameters to describe the hydrophilicity of mineral dust independently of its source and composition. The higher hydrophilicity of mineral dust in the sensitivity simulation results in increased CDNC over areas close to deserts by up to $30 \%$ (e.g., $100 \mathrm{~cm}^{-3}$ over the Sahara and $200 \mathrm{~cm}^{-3}$ over the Gobi and Taklimakan deserts). A notable increase is also calculated over eastern China and northern India (up to $150 \mathrm{~cm}^{-3}$ or $10 \%$ ), where mineral dust is mixed with anthropogenic compounds. These results indicate that changes in the hydrophilicity of the freshly emitted dust, due to the 
variability in its composition with source region, can have an important impact on the calculated CDNC. Remote from the main deserts (e.g., over central Europe), the change in CDNC is negligible since the contribution of mineral dust particles on cloud droplet formation is low. Overall, the calculated global average CDNC increases in the sensitivity simulation by about $5 \%\left(\right.$ or $\left.\sim 12 \mathrm{~cm}^{-3}\right)$.

\subsection{Sensitivity to the emitted dust aerosol load}

The final sensitivity test assumes $50 \%$ lower emissions of mineral dust compared to the reference simulation. The lower tropospheric dust load in the sensitivity simulation (49\%) results in a $10-30 \%$ (up to $150 \mathrm{~cm}^{-3}$ ) decrease in CDNC over the main deserts. On the other hand, CDNC increases over the anthropogenic (e.g., East Asia) and biomass burning (e.g., central Africa) regions by $5-10 \%$ (up to $150 \mathrm{~cm}^{-3}$ ). The opposing responses of CDNC to mineral dust emissions result from the fact that the tropospheric load of the other aerosol species does not change significantly between the two simulations since the chemical and thermodynamic interactions of mineral cations with air pollution remain predominant, even after the $50 \%$ dust emission reduction - i.e., the nitrate abundance rather than that of dust is rate limiting. Therefore, the presence of inorganic anions (e.g., $\mathrm{NO}_{3}^{-}$) in the aerosol phase remains almost unchanged between the two simulations, which results in a decrease in the insoluble fraction of the aerosol, given that mineral dust concentrations are significantly lower in the reference simulation, leading to higher CCN activity. Over the Taklimakan desert the insoluble fraction of the aerosol changes by less than $10 \%$, and therefore the change in aerosol number concentration $(\sim 40 \%)$ due to the mineral dust emission change dominates the effect on CDNC, which is calculated to be about $100 \mathrm{~cm}^{-3}$ (or $\sim 20 \%$ ) lower in the sensitivity simulation. On the other hand, over Southeast Asia, the aerosol number concentration changes less than $10 \%$ as the insoluble fraction of the aerosols decreases by $40 \%$. The significant decrease in $\varepsilon_{i}$ in Eq. (3) affects the calculated critical supersaturation of the particle as well as the exponent $x$ in Eq. (4), resulting in an increase in CDNC by about $150 \mathrm{~cm}^{-3}$ (or $\sim 10 \%$ ). Overall, the impact of halving mineral dust emissions on the calculated global average CDNC is remarkably small $(\sim 3 \%$ or $\left.6 \mathrm{~cm}^{-3}\right)$.

\section{Summary and conclusions}

This study assesses the impact of mineral dust on global cloud droplet number concentrations by using an interactive aerosol-chemistry-cloud-climate model (EMAC). The "unified dust activation framework" (UAF) has been implemented into the EMAC model to account for the effects of dust particles through both the hydrophilicity from adsorption and the acquired hygroscopicity from pollution solutes (chemical aging) on $\mathrm{CCN}$ activity calculations. The calculation of cloud droplet formation from soluble particles is carried out by using the $\kappa$-Köhler theory, while that of insoluble particles is based on the FHH multilayer adsorption isotherm approach. For atmospheric particles that contain a substantial fraction of both soluble (e.g., nitrate) and insoluble material (e.g., mineral dust), cloud formation is calculated using the UAF, which determines the maximum equilibrium water vapor supersaturation over an aerosol consisting of an insoluble core with a soluble coating. Furthermore, the model setup includes thermodynamic interactions between mineral dust anions (i.e., $\mathrm{Na}^{+}, \mathrm{Ca}^{2+}, \mathrm{K}^{+}, \mathrm{Mg}^{2+}$ ) and inorganic cations (i.e., $\left.\mathrm{NO}_{3}^{-}, \mathrm{Cl}^{-}, \mathrm{SO}_{4}^{2-}\right)$.

The simulated CDNC at $940 \mathrm{hPa}$, i.e., at cloud base, is relatively high over the industrialized areas of Europe, Asia and North America (exceeding $1000 \mathrm{~cm}^{-3}$ ) and over the biomass burning regions in the tropics $\left(300-700 \mathrm{~cm}^{-3}\right)$. Relatively high CDNC is also calculated over the main deserts $\left(100-1000 \mathrm{~cm}^{-3}\right)$, where the CCN activity of pristine mineral dust is enhanced by chemical and thermodynamic interactions with soluble compounds from anthropogenic (including biomass burning) and natural sources. Low CDNC (around $50 \mathrm{~cm}^{-3}$ ) is calculated over the remote oceans, while CDNC is much higher (up to $1000 \mathrm{~cm}^{-3}$ ) over more polluted marine regions near the coast. In view of CDNC from in situ and satellite observations, we conclude that the model tends to underestimate CDNC over clean marine areas and overestimates CDNC over polluted regions. In the current application, CDNC represents an upper limit with respect to the comparison with observations since we have not accounted for droplet depletion through collision and coalescence processes. However, the model tendency to overestimate the high values of CDNC has a small impact on the overall cloud radiative forcing since the sensitivity of cloud albedo to CDNC over polluted areas is low (Seinfeld and Pandis, 2006).

To estimate the effects of mineral dust and its variable chemical composition on CDNC, three main sensitivity simulations have been conducted. In the first, mineral dust emissions were switched off. This reveals that despite the large tropospheric load of mineral dust aerosols (35 Tg in the base case simulation) the dust presence decreases the calculated global average CDNC by only $11 \%$. This is the net result of substantial positive and negative, partly compensating effects. Over polluted regions (e.g., Europe), dust particles, mostly transported from the Sahara, are mixed with pollution aerosols, resulting in a significant reduction of the $\mathrm{CCN}$ activity of the anthropogenic particles and hence cloud droplet formation. On the other hand, the activation of freshly emitted dust particles through water adsorption results in an increase in CDNC over the main deserts. However, on a global scale this is not equivalent to the calculated decrease over the polluted regions. While such sensitivity tests do not relate to real-world changes, they help understand the role of mineral dust in the climate system, and especially the importance of 
including these processes, being hitherto neglected, into climate models.

A second simulation has been performed by switching off the mineral dust chemistry to estimate the impact of interactions between inorganic and mineral cations on the predicted CDNC. We find that the tropospheric burden of inorganic anions (mainly nitrate) increases, resulting in a slight increase in $\mathrm{CCN}$ activity and cloud droplet formation efficiency in areas that are influenced by biomass burning and industrial emissions. Furthermore, including crustal cation chemistry and thermodynamics significantly affects the aging of mineral dust and its solubility, especially due to the uptake of nitric acid, so that dust is removed more efficiently through wet and dry deposition. This results in a decrease in CDNC over the remote deserts (e.g., Taklimakan). Irrespective of the regional differences, the global average CDNC does not change significantly by considering mineral dust chemistry and thermodynamics.

In the third simulation, the FHH calculations have been switched off to estimate the effects of water adsorption onto the surface of insoluble dust particles on the predicted CDNC. The CDNC in the reference simulation is found to be higher over arid areas due to the adsorption activation of the freshly emitted insoluble dust particles. On the other hand, CDNC is lower over polluted regions (e.g., over Europe) since the aged dust particles experience significant water uptake during their activation reducing the $s_{\max }$ and the activation of the smaller anthropogenic particles. Overall, the use of the UAF results in a decrease in the global average CDNC by $\sim 10 \%$. This result shows that for the modeling of cloud droplet formation, adsorption activation of insoluble aerosols can be more important than mineral dust chemistry and thermodynamics. However, taking into account the adsorption activation of insoluble aerosols without mineral dust chemistry can result in a significant overestimation of CDNC, mainly over the remote deserts. Conversely, considering mineral dust chemistry and thermodynamics without UAF can result in significant overestimation of CDNC over polluted areas.

Finally, three additional sensitivity simulations have been conducted to investigate the sensitivity of the results to the physicochemical properties of the emitted mineral dust (chemical composition, hydrophilicity and emission strength). The results indicate that the calculated CDNC can be regionally sensitive to the mineral dust hydrophilicity and emission load. Nevertheless, by assuming drastic differences in the dust source and the dust hydrophilicity, we find only small $(\sim 5 \%)$ changes in the global average CDNC. Larger CDNC changes are calculated over the main deserts (up to $30 \%$ ) and over highly polluted areas (up to $10 \%$ ). Further, we find that the global average CDNC is not sensitive to the chemical composition of mineral dust.

This study demonstrates that a comprehensive treatment of the CCN activity of mineral dust aerosols and their chemical and thermodynamic interactions with inorganic species by CCMs is important to realistically account for aerosolchemistry-cloud-climate interactions. Neglecting the adsorption activation of freshly emitted dust can result in significant biases over areas close to deserts. In addition, neglecting the mineral dust chemistry and thermodynamics results in an underestimation of the coating of dust by hygroscopic salts during atmospheric aging. The realistic representation of soluble coating on dust is crucial since it affects its efficiency to grow by water uptake, which significantly influences the local supersaturation and thus cloud droplet formation over anthropogenically polluted regions. In this first study we apply the UAF diagnostically, while in future applications, e.g., to simulate climate responses, we plan prognostic calculations where effects on precipitation formation and dynamical responses will also be accounted for.

Data availability. The data in the study are available from the authors upon request (v.karydis@mpic.de).

Competing interests. The authors declare that they have no conflict of interest.

Acknowledgements. V. A. Karydis acknowledges support from a FP7 Marie Curie Career Integration Grant (project reference 618349). A. P. Tsimpidi acknowledges support from a DFG individual grant program (project reference TS 335/2-1).

The article processing charges for this open-access publication were covered by the Max Planck Society.

Edited by: E. Harris

Reviewed by: two anonymous referees

\section{References}

Abdelkader, M., Metzger, S., Mamouri, R. E., Astitha, M., Barrie, L., Levin, Z., and Lelieveld, J.: Dust-air pollution dynamics over the eastern Mediterranean, Atmos. Chem. Phys., 15, 9173-9189, doi:10.5194/acp-15-9173-2015, 2015.

Albrecht, B. A.: Aerosols, cloud microphysics, and fractional cloudiness, Science, 245, 1227-1230, 1989.

Andreae, M. O. and Rosenfeld, D.: Aerosol-cloud-precipitation interactions. Part 1. The nature and sources of cloud-active aerosols, Earth-Sci. Rev., 89, 13-41, 2008.

Astitha, M., Lelieveld, J., Abdel Kader, M., Pozzer, A., and de Meij, A.: Parameterization of dust emissions in the global atmospheric chemistry-climate model EMAC: impact of nudging and soil properties, Atmos. Chem. Phys., 12, 11057-11083, doi:10.5194/acp-12-11057-2012, 2012.

Bangert, M., Nenes, A., Vogel, B., Vogel, H., Barahona, D., Karydis, V. A., Kumar, P., Kottmeier, C., and Blahak, U.: Saharan dust event impacts on cloud formation and radiation over Western Eu- 
rope, Atmos. Chem. Phys., 12, 4045-4063, doi:10.5194/acp-124045-2012, 2012.

Barahona, D. and Nenes, A.: Parameterization of cloud droplet formation in large-scale models: Including effects of entrainment, J. Geophys. Res., 112, D16206, doi:10.1029/2007JD008473, 2007.

Barahona, D., West, R. E. L., Stier, P., Romakkaniemi, S., Kokkola, H., and Nenes, A.: Comprehensively accounting for the effect of giant $\mathrm{CCN}$ in cloud activation parameterizations, Atmos. Chem. Phys., 10, 2467-2473, doi:10.5194/acp-10-2467-2010, 2010.

Bègue, N., Tulet, P., Pelon, J., Aouizerats, B., Berger, A., and Schwarzenboeck, A.: Aerosol processing and CCN formation of an intense Saharan dust plume during the EUCAARI 2008 campaign, Atmos. Chem. Phys., 15, 3497-3516, doi:10.5194/acp-153497-2015, 2015.

Bennartz, R.: Global assessment of marine boundary layer cloud droplet number concentration from satellite, J. Geophys. Res., 112, D16302, doi:10.1029/2006JD007547, 2007.

Bougiatioti, A., Bezantakos, S., Stavroulas, I., Kalivitis, N., Kokkalis, P., Biskos, G., Mihalopoulos, N., Papayannis, A., and Nenes, A.: Biomass-burning impact on CCN number, hygroscopicity and cloud formation during summertime in the eastern Mediterranean, Atmos. Chem. Phys., 16, 7389-7409, doi:10.5194/acp-16-7389-2016, 2016a.

Bougiatioti, A., Nikolaou, P., Stavroulas, I., Kouvarakis, G., Weber, R., Nenes, A., Kanakidou, M., and Mihalopoulos, N.: Particle water and $\mathrm{pH}$ in the eastern Mediterranean: source variability and implications for nutrient availability, Atmos. Chem. Phys., 16, 4579-4591, doi:10.5194/acp-16-4579-2016, $2016 \mathrm{~b}$.

Bouwman, A. F., Lee, D. S., Asman, W. A. H., Dentener, F. J., VanderHoek, K. W., and Olivier, J. G. J.: A global high-resolution emission inventory for ammonia, Global Biogeochem. Cy., 11, 561-587, 1997.

Bower, K. N., Choularton, T. W., Gallagher, M. W., Colvile, R. N., Beswick, K. M., Inglis, D. W. F., Bradbury, C., Martinsson, B. G., Swietlicki, E., Berg, O. H., Cederfelt, S. I., Frank, G., Zhou, J., Cape, J. N., Sutton, M. A., McFadyen, G. G., Milford, C., Birmili, W., Yuskiewicz, B. A., Wiedensohler, A., Stratmann, F., Wendisch, M., Berner, A., Ctyroky, P., Galambos, Z., Mesfin, S. H., Dusek, U., Dore, C. J., Lee, D. S., Pepler, S. A., Bizjak, M., and Divjak, B.: The Great Dun Fell Experiment 1995: an overview, Atmos. Res., 50, 151-184, 1999.

Capps, S. L., Henze, D. K., Hakami, A., Russell, A. G., and Nenes, A.: ANISORROPIA: the adjoint of the aerosol thermodynamic model ISORROPIA, Atmos. Chem. Phys., 12, 527-543, doi:10.5194/acp-12-527-2012, 2012.

Clarke, L., Edmonds, J., Jacoby, H., Pitcher, H., Reilly, J., and Richels, R.: Scenarios of greenhouse gas emissions and atmospheric concentrations (Part A) and review of integrated scenario development and application (Part B). A report by the U.S. climate change science program and the subcommittee on global change research, Department of Energy, Office of Biological and Environmental Research, Washington, D.C., USA, 2007.

Considine, D. B., Bergmann, D. J., and Liu, H.: Sensitivity of Global Modeling Initiative chemistry and transport model simulations of radon-222 and lead-210 to input meteorological data, Atmos. Chem. Phys., 5, 3389-3406, doi:10.5194/acp-5-33892005, 2005.

Dall'Osto, M., Harrison, R. M., Highwood, E. J., O’Dowd, C., Ceburnis, D., Querol, X., and Achterberg, E. P.: Variation of the mixing state of Saharan dust particles with atmospheric transport, Atmos. Environ., 44, 3135-3146, 2010.

de Meij, A., Pozzer, A., Pringle, K. J., Tost, H., and Lelieveld, J.: EMAC model evaluation and analysis of atmospheric aerosol properties and distribution with a focus on the Mediterranean region, Atmos. Res., 114, 38-69, 2012.

Dentener, F., Kinne, S., Bond, T., Boucher, O., Cofala, J., Generoso, S., Ginoux, P., Gong, S., Hoelzemann, J. J., Ito, A., Marelli, L., Penner, J. E., Putaud, J.-P., Textor, C., Schulz, M., van der Werf, G. R., and Wilson, J.: Emissions of primary aerosol and precursor gases in the years 2000 and 1750 prescribed data-sets for AeroCom, Atmos. Chem. Phys., 6, 4321-4344, doi:10.5194/acp-64321-2006, 2006.

Doering, U., van Aardenne, J., Monni, S., Pagliari, V., Orlandini, L., and SanMartin, F.: CIRCE report D8.1.3 - Update of gridded emission inventories, addition of period 1990-2005 and the years 2010, 2015, 2050, Tech. rep., Project FP6: 6.3, No. 036961, CIRCE, Rome, Italy, 2009.

Dong, X. Q. and Mace, G. G.: Arctic stratus cloud properties and radiative forcing derived from ground-based data collected at Barrow, Alaska, J. Climate, 16, 445-461, 2003.

Drozd, G., Woo, J., Häkkinen, S. A. K., Nenes, A., and McNeill, V. F.: Inorganic salts interact with oxalic acid in submicron particles to form material with low hygroscopicity and volatility, Atmos. Chem. Phys., 14, 5205-5215, doi:10.5194/acp-14-52052014, 2014.

Fairlie, T. D., Jacob, D. J., Dibb, J. E., Alexander, B., Avery, M. A., van Donkelaar, A., and Zhang, L.: Impact of mineral dust on nitrate, sulfate, and ozone in transpacific Asian pollution plumes, Atmos. Chem. Phys., 10, 3999-4012, doi:10.5194/acp-10-39992010, 2010.

Falkovich, A. H., Ganor, E., Levin, Z., Formenti, P., and Rudich, Y.: Chemical and mineralogical analysis of individual mineral dust particles, J. Geophys. Res.-Atmos., 106, 18029-18036, 2001.

Feingold, G., Cotton, W. R., Kreidenweis, S. M., and Davis, J. T.: The impact of giant cloud condensation nuclei on drizzle formation in stratocumulus: Implications for cloud radiative properties, J. Atmos. Sci., 56, 4100-4117, 1999.

Feng, Y. and Penner, J. E.: Global modeling of nitrate and ammonium: Interaction of aerosols and tropospheric chemistry, J. Geophys. Res.-Atmos., 112, D001304, doi:10.1029/2005JD006404, 2007.

Fountoukis, C. and Nenes, A.: Continued development of a cloud droplet formation parameterization for global climate models, J. Geophys. Res., 110, D11212, doi:10.1029/2004JD005591, 2005.

Fountoukis, C. and Nenes, A.: ISORROPIA II: a computationally efficient thermodynamic equilibrium model for $\mathrm{K}^{+}$. $\mathrm{Ca}^{2+}-\mathrm{Mg}^{2+}-\mathrm{NH}_{4}^{+}-\mathrm{Na}^{+}-\mathrm{SO}_{4}^{2-}-\mathrm{NO}_{3}^{-}-\mathrm{Cl}^{-}-\mathrm{H}_{2} \mathrm{O}$ aerosols, Atmos. Chem. Phys., 7, 4639-4659, doi:10.5194/acp-7-4639-2007, 2007.

Fountoukis, C., Nenes, A., Meskhidze, N., Bahreini, R., Conant, W. C., Jonsson, H., Murphy, S., Sorooshian, A., Varutbangkul, V., Brechtel, F., Flagan, R. C., and Seinfeld, J. H.: Aerosolcloud drop concentration closure for clouds sampled during the International Consortium for Atmos. Res. on Transport and Transformation 2004 campaign, J. Geophys. Res., 112, D10S30, doi:10.1029/2006JD007272, 2007.

Fountoukis, C., Nenes, A., Sullivan, A., Weber, R., Van Reken, T., Fischer, M., Matías, E., Moya, M., Farmer, D., and Cohen, 
R. C.: Thermodynamic characterization of Mexico City aerosol during MILAGRO 2006, Atmos. Chem. Phys., 9, 2141-2156, doi:10.5194/acp-9-2141-2009, 2009.

Gantt, B., He, J., Zhang, X., Zhang, Y., and Nenes, A.: Incorporation of advanced aerosol activation treatments into CESM/CAM5: model evaluation and impacts on aerosol indirect effects, Atmos. Chem. Phys., 14, 7485-7497, doi:10.5194/acp-14-74852014, 2014.

Ganzeveld, L. N., Lelieveld, J., Dentener, F. J., Krol, M. C., Bouwman, A. J., and Roelofs, G. J.: Global soil-biogenic $\mathrm{NO}_{x}$ emissions and the role of canopy processes, J. Geophys. Res.-Atmos., 107, 4298, doi:10.1029/2001JD001289, 2002.

Garimella, S., Huang, Y.-W., Seewald, J. S., and Cziczo, D. J.: Cloud condensation nucleus activity comparison of dry- and wetgenerated mineral dust aerosol: the significance of soluble material, Atmos. Chem. Phys., 14, 6003-6019, doi:10.5194/acp-146003-2014, 2014.

Giannadaki, D., Pozzer, A., and Lelieveld, J.: Modeled global effects of airborne desert dust on air quality and premature mortality, Atmos. Chem. Phys., 14, 957-968, doi:10.5194/acp-14-9572014, 2014.

Grewe, V., Brunner, D., Dameris, M., Grenfell, J. L., Hein, R., Shindell, D., and Staehelin, J.: Origin and variability of upper tropospheric nitrogen oxides and ozone at northern mid-latitudes, Atmos. Environ., 35, 3421-3433, 2001.

Grini, A., Myhre, G., Zender, C. S., and Isaksen, I. S. A.: Model simulations of dust sources and transport in the global atmosphere: Effects of soil erodibility and wind speed variability, J. Geophys. Res., 110, D02205, doi:10.1029/2004JD005037, 2005.

Gustafsson, R. J., Orlov, A., Badger, C. L., Griffiths, P. T., Cox, R. A., and Lambert, R. M.: A comprehensive evaluation of water uptake on atmospherically relevant mineral surfaces: DRIFT spectroscopy, thermogravimetric analysis and aerosol growth measurements, Atmos. Chem. Phys., 5, 3415-3421, doi:10.5194/acp-5-3415-2005, 2005.

Hatch, C. D., Greenaway, A. L., Christie, M. J., and Baltrusaitis, J.: Water adsorption constrained Frenkel-Halsey-Hill adsorption activation theory: Montmorillonite and illite, Atmos. Environ., 87, 26-33, 2014.

Hauglustaine, D. A., Balkanski, Y., and Schulz, M.: A global model simulation of present and future nitrate aerosols and their direct radiative forcing of climate, Atmos. Chem. Phys., 14, 1103111063, doi:10.5194/acp-14-11031-2014, 2014.

Haywood, J. and Boucher, O.: Estimates of the direct and indirect radiative forcing due to tropospheric aerosols: A review, Rev. Geophys., 38, 513-543, 2000.

Herich, H., Tritscher, T., Wiacek, A., Gysel, M., Weingartner, E., Lohmann, U., Baltensperger, U., and Cziczo, D. J.: Water uptake of clay and desert dust aerosol particles at sub- and supersaturated water vapor conditions, Phys. Chem. Chem. Phys., 11, 7804-7809, 2009.

IPCC (Intergovernmental Panel on Climate Change): The physical science basis. Contribution of working group I to the fifth assessment report of the intergovernmental panel on climate change, edited by: Stocker, T. F., Qin, D., Plattner, G.-K., Tignor, M., Allen, S. K., Boschung, J., Nauels, A., Xia, Y., Bex, V., and Midgley, P. M., Cambridge University Press, Cambridge, UK and New York, NY, USA, 2013.
Jeuken, A. B. M., Siegmund, P. C., Heijboer, L. C., Feichter, J., and Bengtsson, L.: On the potential of assimilating meteorological analyses in a global climate model for the purpose of model validation, J. Geophys. Res.-Atmos., 101, 16939-16950, 1996.

Jöckel, P., Tost, H., Pozzer, A., Brühl, C., Buchholz, J., Ganzeveld, L., Hoor, P., Kerkweg, A., Lawrence, M. G., Sander, R., Steil, B., Stiller, G., Tanarhte, M., Taraborrelli, D., van Aardenne, J., and Lelieveld, J.: The atmospheric chemistry general circulation model ECHAM5/MESSy1: consistent simulation of ozone from the surface to the mesosphere, Atmos. Chem. Phys., 6, 50675104, doi:10.5194/acp-6-5067-2006, 2006.

Jöckel, P., Kerkweg, A., Pozzer, A., Sander, R., Tost, H., Riede, H., Baumgaertner, A., Gromov, S., and Kern, B.: Development cycle 2 of the Modular Earth Submodel System (MESSy2), Geosci. Model Dev., 3, 717-752, doi:10.5194/gmd-3-717-2010, 2010.

Kalkavouras, P., Bossioli, E., Bezantakos, S., Bougiatioti, A., Kalivitis, N., Stavroulas, I., Kouvarakis, G., Protonotariou, A. P., Dandou, A., Biskos, G., Mihalopoulos, N., Nenes, A., and Tombrou, M.: New particle formation in the southern Aegean Sea during the Etesians: importance for $\mathrm{CCN}$ production and cloud droplet number, Atmos. Chem. Phys., 17, 175-192, doi:10.5194/acp-17-175-2017, 2017.

Kallos, G., Solomos, S., Kushta, J., Mitsakou, C., Spyrou, C., Bartsotas, N., and Kalogeri, C.: Natural and anthropogenic aerosols in the Eastern Mediterranean and Middle East: Possible impacts, Sci. Total Environ., 488, 391-399, 2014.

Karydis, V. A., Kumar, P., Barahona, D., Sokolik, I. N., and Nenes, A.: On the effect of dust particles on global cloud condensation nuclei and cloud droplet number, J. Geophys. Res.-Atmos., 116, D23204, doi:10.1029/2011JD016283, 2011a.

Karydis, V. A., Tsimpidi, A. P., Lei, W., Molina, L. T., and Pandis, S. N.: Formation of semivolatile inorganic aerosols in the Mexico City Metropolitan Area during the MILAGRO campaign, Atmos. Chem. Phys., 11, 13305-13323, doi:10.5194/acp11-13305-2011, 2011b.

Karydis, V. A., Capps, S. L., Russell, A. G., and Nenes, A.: Adjoint sensitivity of global cloud droplet number to aerosol and dynamical parameters, Atmos. Chem. Phys., 12, 9041-9055, doi:10.5194/acp-12-9041-2012, 2012.

Karydis, V. A., Tsimpidi, A. P., Pozzer, A., Astitha, M., and Lelieveld, J.: Effects of mineral dust on global atmospheric nitrate concentrations, Atmos. Chem. Phys., 16, 1491-1509, doi:10.5194/acp-16-1491-2016, 2016.

Kelly, J. T., Chuang, C. C., and Wexler, A. S.: Influence of dust composition on cloud droplet formation, Atmos. Environ., 41, 2904-2916, 2007.

Kerkweg, A., Buchholz, J., Ganzeveld, L., Pozzer, A., Tost, H., and Jöckel, P.: Technical Note: An implementation of the dry removal processes DRY DEPosition and SEDImentation in the Modular Earth Submodel System (MESSy), Atmos. Chem. Phys., 6, 4617-4632, doi:10.5194/acp-6-4617-2006, 2006.

Koch, D., Bauer, S. E., Del Genio, A., Faluvegi, G., McConnell, J. R., Menon, S., Miller, R. L., Rind, D., Ruedy, R., Schmidt, G. A., and Shindell, D.: Coupled Aerosol-Chemistry-Climate Twentieth-Century Transient Model Investigation: Trends in Short-Lived Species and Climate Responses, J. Climate, 24, 2693-2714, 2011.

Koehler, K. A., Kreidenweis, S. M., DeMott, P. J., Petters, M. D., Prenni, A. J., and Carrico, C. M.: Hygroscopicity and cloud 
droplet activation of mineral dust aerosol, Geophys. Res. Lett., 36, L08805, doi:10.1029/2009GL037348, 2009.

Kumar, P., Nenes, A., and Sokolik, I. N.: Importance of adsorption for CCN activity and hygroscopic properties of mineral dust aerosol, Geophys. Res. Lett., 36, doi:10.1029/2009GL040827, 2009a.

Kumar, P., Sokolik, I. N., and Nenes, A.: Parameterization of cloud droplet formation for global and regional models: including adsorption activation from insoluble CCN, Atmos. Chem. Phys., 9, 2517-2532, doi:10.5194/acp-9-2517-2009, 2009b.

Kumar, P., Sokolik, I. N., and Nenes, A.: Cloud condensation nuclei activity and droplet activation kinetics of wet processed regional dust samples and minerals, Atmos. Chem. Phys., 11, 8661-8676, doi:10.5194/acp-11-8661-2011, 2011a.

Kumar, P., Sokolik, I. N., and Nenes, A.: Measurements of cloud condensation nuclei activity and droplet activation kinetics of fresh unprocessed regional dust samples and minerals, Atmos. Chem. Phys., 11, 3527-3541, doi:10.5194/acp-11-3527-2011, $2011 b$.

Kushta, J., Kallos, G., Astitha, M., Solomos, S., Spyrou, C., Mitsakou, C., and Lelieveld, J.: Impact of natural aerosols on atmospheric radiation and consequent feedbacks with the meteorological and photochemical state of the atmosphere, J. Geophys. Res.-Atmos., 119, 1463-1491, 2014.

Laaksonen, A., Malila, J., Nenes, A., Hung, H. M., and Chen, J. P.: Surface fractal dimension, water adsorption efficiency, and cloud nucleation activity of insoluble aerosol, Sci. Rep., 6, 25504, doi:10.1038/srep25504, 2016.

Lathem, T. L., Kumar, P., Nenes, A., Dufek, J., Sokolik, I. N., Trail, M., and Russell, A.: Hygroscopic properties of volcanic ash, Geophys. Res. Lett., 38, L11802, doi:10.1029/2011GL047298, 2011.

Leibensperger, E. M., Mickley, L. J., Jacob, D. J., Chen, W.-T., Seinfeld, J. H., Nenes, A., Adams, P. J., Streets, D. G., Kumar, N., and Rind, D.: Climatic effects of 1950-2050 changes in US anthropogenic aerosols - Part 1: Aerosol trends and radiative forcing, Atmos. Chem. Phys., 12, 3333-3348, doi:10.5194/acp-12-33332012, 2012.

Lelieveld, J., Evans, J. S., Fnais, M., Giannadaki, D., and Pozzer, A.: The contribution of outdoor air pollution sources to premature mortality on a global scale, Nature, 525, 367-371, 2015.

Levin, Z., Teller, A., Ganor, E., and Yin, Y.: On the interactions of mineral dust, sea-salt particles, and clouds: A measurement and modeling study from the Mediterranean Israeli Dust Experiment campaign, J. Geophys. Res., 110, D20202, doi:10.1029/2005JD005810, 2005.

Liao, H., Adams, P. J., Chung, S. H., Seinfeld, J. H., Mickley, L. J., and Jacob, D. J.: Interactions between tropospheric chemistry and aerosols in a unified general circulation model, J. Geophys. Res.-Atmos., 108, 4001, doi:10.1029/2001JD001260, 2003.

Lohmann, U. and Feichter, J.: Global indirect aerosol effects: a review, Atmos. Chem. Phys., 5, 715-737, doi:10.5194/acp-5-7152005, 2005.

Lohmann, U. and Ferrachat, S.: Impact of parametric uncertainties on the present-day climate and on the anthropogenic aerosol effect, Atmos. Chem. Phys., 10, 11373-11383, doi:10.5194/acp10-11373-2010, 2010.
Lohmann, U., Feichter, J., Chuang, C. C., and Penner, J. E.: Prediction of the number of cloud droplets in the ECHAM GCM, J Geophys. Res.-Atmos., 104, 9169-9198, 1999a.

Lohmann, U., McFarlane, N., Levkov, L., Abdella, K., and Albers, F.: Comparing different cloud schemes of a single column model by using mesoscale forcing and nudging technique, J. Climate, 12, 438-461, 1999b.

Ma, J., Chen, Y., Wang, W., Yan, P., Liu, H., Yang, S., Hu, Z., and Lelieveld, J.: Strong air pollution causes widespread hazeclouds over China, J. Geophys. Res.-Atmos., 115, D18204, doi:10.1029/2009JD013065, 2010.

Martin, G. M., Johnson, D. W., and Spice, A.: The measurements and Parameterization of Effective Radius of Droplets in Warm Stratocumulus Clouds, J. Atmos. Sci., 51, 1823-1842, 1993.

Martin, R. V., Jacob, D. J., Yantosca, R. M., Chin, M., and Ginoux, P.: Global and regional decreases in tropospheric oxidants from photochemical effects of aerosols, J. Geophys. Res.-Atmos., 108, 4097, doi:10.1029/2002JD002622, 2003.

Meskhidze, N., Nenes, A., Conant, W. C., and Seinfeld, J. H.: Evaluation of a new cloud droplet activation parameterization with in situ data from CRYSTAL-FACE and CSTRIPE, J. Geophys. Res., 110, D16202, doi:10.1029/2004JD005703, 2005.

Morales, R. and Nenes, A.: Characteristic updrafts for computing distribution-averaged cloud droplet number and stratocumulus cloud properties, J. Geophys. Res., 115, D18220, doi:10.1029/2009JD013233, 2010.

Morales, R., Nenes, A., Jonsson, H., Flagan, R. C., and Seinfeld, J. H.: Evaluation of an entraining droplet activation parameterization using in situ cloud data, J. Geophys. Res.-Atmos., 116, D15205, doi:10.1029/2010jd015324, 2011.

Morales Betancourt, R. and Nenes, A.: Droplet activation parameterization: the population-splitting concept revisited, Geosci. Model Dev., 7, 2345-2357, doi:10.5194/gmd-7-2345-2014, 2014a.

Morales Betancourt, R. and Nenes, A.: Understanding the contributions of aerosol properties and parameterization discrepancies to droplet number variability in a global climate model, Atmos. Chem. Phys., 14, 4809-4826, doi:10.5194/acp-14-48092014, 2014b.

Nenes, A. and Seinfeld, J. H.: Parameterization of cloud droplet formation in global climate models, J. Geophys. Res., 108, 4415, doi:10.1029/2002JD002911, 2003.

Perry, K. D., Cliff, S. S., and Jimenez-Cruz, M. P.: Evidence for hygroscopic mineral dust particles from the Intercontinental Transport and Chemical Transformation Experiment, J. Geophys. Res.-Atmos., 109, D23S28, doi:10.1029/2004JD004979, 2004.

Petters, M. D. and Kreidenweis, S. M.: A single parameter representation of hygroscopic growth and cloud condensation nucleus activity, Atmos. Chem. Phys., 7, 1961-1971, doi:10.5194/acp-71961-2007, 2007.

Pozzer, A., Jöckel, P., Sander, R., Williams, J., Ganzeveld, L., and Lelieveld, J.: Technical Note: The MESSy-submodel AIRSEA calculating the air-sea exchange of chemical species, Atmos. Chem. Phys., 6, 5435-5444, doi:10.5194/acp-6-5435-2006, 2006.

Pozzer, A., Jöckel, P., and Van Aardenne, J.: The influence of the vertical distribution of emissions on tropospheric chemistry, At- 
mos. Chem. Phys., 9, 9417-9432, doi:10.5194/acp-9-9417-2009, 2009.

Pozzer, A., de Meij, A., Pringle, K. J., Tost, H., Doering, U. M., van Aardenne, J., and Lelieveld, J.: Distributions and regional budgets of aerosols and their precursors simulated with the EMAC chemistry-climate model, Atmos. Chem. Phys., 12, 961-987, doi:10.5194/acp-12-961-2012, 2012.

Pringle, K. J., Tost, H., Message, S., Steil, B., Giannadaki, D., Nenes, A., Fountoukis, C., Stier, P., Vignati, E., and Lelieveld, J.: Description and evaluation of GMXe: a new aerosol submodel for global simulations (v1), Geosci. Model Dev., 3, 391-412, doi:10.5194/gmd-3-391-2010, 2010.

Rausch, J., Heidinger, A., and Bennartz, R.: Regional assessment of microphysical properties of marine boundary layer cloud using the PATMOS-x dataset, J. Geophys. Res., 115, D23212, doi:10.1029/2010JD014468, 2010.

Roberts, G., Mauger, G., Hadley, O., and Ramanathan, V.: North American and Asian aerosols over the eastern Pacific Ocean and their role in regulating cloud condensation nuclei, J. Geophys. Res.-Atmos., 111, D13205, doi:10.1029/2005JD006661, 2006.

Röckner, E., Brokopf, R., Esch, M., Giorgetta, M., Hagemann, S., Kornblueh, L., Manzini, E., Schlese, U., and Schulzweida, U.: Sensitivity of simulated climate to horizontal and vertical resolution in the ECHAM5 atmosphere model, J. Climate, 19, 37713791, 2006.

Rosenfeld, D., Clavner, M., and Nirel, R.: Pollution and dust aerosols modulating tropical cyclones intensities, Atmos. Res., 102, 66-76, 2011.

Sander, R., Baumgaertner, A., Gromov, S., Harder, H., Jöckel, P., Kerkweg, A., Kubistin, D., Regelin, E., Riede, H., Sandu, A., Taraborrelli, D., Tost, H., and Xie, Z.-Q.: The atmospheric chemistry box model CAABA/MECCA-3.0, Geosci. Model Dev., 4, 373-380, doi:10.5194/gmd-4-373-2011, 2011.

Schwartz, S. E.: Cloud droplet nucleation and its connection to aerosol properties, in: Nucleation and Atmospheric Aerosols, edited by: Kulmala, M. and Wagner, P. E., Elsevier, Oxford, UK, 1996.

Seinfeld, J. H. and Pandis, S. N.: Atmospheric Chemistry and Physics: From Air Pollution to Climate Change, John Wiley \& Sons, Inc., Hoboken, New Jersey, USA, 2006.

Smoydzin, L., Teller, A., Tost, H., Fnais, M., and Lelieveld, J.: Impact of mineral dust on cloud formation in a Saharan outflow region, Atmos. Chem. Phys., 12, 11383-11393, doi:10.5194/acp12-11383-2012, 2012.

Sorjamaa, R. and Laaksonen, A.: The effect of $\mathrm{H}_{2} \mathrm{O}$ adsorption on cloud drop activation of insoluble particles: a theoretical framework, Atmos. Chem. Phys., 7, 6175-6180, doi:10.5194/acp-76175-2007, 2007.

Sposito, G.: The Chemistry of Soils, Oxford university Press, New York, USA, 1989.

Stone, E. A., Yoon, S.-C., and Schauer, J. J.: Chemical Characterization of Fine and Coarse Particles in Gosan, Korea during Springtime Dust Events, Aerosol Air Qual. Res., 11, 31-43, 2011.

Sullivan, R. C., Guazzotti, S. A., Sodeman, D. A., and Prather, K. A.: Direct observations of the atmospheric processing of Asian mineral dust, Atmos. Chem. Phys., 7, 1213-1236, doi:10.5194/acp-7-1213-2007, 2007.

Sullivan, R. C., Moore, M. J. K., Petters, M. D., Kreidenweis, S. M., Roberts, G. C., and Prather, K. A.: Effect of chemical mixing state on the hygroscopicity and cloud nucleation properties of calcium mineral dust particles, Atmos. Chem. Phys., 9, 33033316, doi:10.5194/acp-9-3303-2009, 2009.

Tobo, Y., Zhang, D., Matsuki, A., and Iwasaka, Y.: Asian dust particles converted into aqueous droplets under remote marine atmospheric conditions, P. Natl. Acad. Sci. USA, 107, 17905-17910, 2010.

Tost, H., Jöckel, P., Kerkweg, A., Sander, R., and Lelieveld, J.: Technical note: A new comprehensive SCAVenging submodel for global atmospheric chemistry modelling, Atmos. Chem. Phys., 6, 565-574, doi:10.5194/acp-6-565-2006, 2006.

Tsimpidi, A. P., Karydis, V. A., Pozzer, A., Pandis, S. N., and Lelieveld, J.: ORACLE (v1.0): module to simulate the organic aerosol composition and evolution in the atmosphere, Geosci. Model Dev., 7, 3153-3172, doi:10.5194/gmd-7-31532014, 2014.

Tsimpidi, A. P., Karydis, V. A., Pandis, S. N., and Lelieveld, J.: Global combustion sources of organic aerosols: model comparison with 84 AMS factor-analysis data sets, Atmos. Chem. Phys., 16, 8939-8962, doi:10.5194/acp-16-8939-2016, 2016.

Tsimpidi, A. P., Karydis, V. A., Pandis, S. N., and Lelieveld, J.: Global-scale combustion sources of organic aerosols: Sensitivity to formation and removal mechanisms, Atmos. Chem. Phys. Discuss., doi:10.5194/acp-2017-6, in review, 2017.

Twohy, C. H., Kreidenweis, S. M., Eidhammer, T., Browell, E. V., Heymsfield, A. J., Bansemer, A. R., Anderson, B. E., Chen, G., Ismail, S., DeMott, P. J., and Van den Heever, S. C.: Saharan dust particles nucleate droplets in eastern Atlantic clouds, Geophys. Res. Lett., 36, L01807, doi:10.1029/2008GL035846, 2009.

Twomey, S.: Pollution and planetary albedo, Atmos. Environ., 8, 1251-1256, 1974.

Twomey, S. and Wojciechowski, T. A.: Observations of the Geographical Variation of Cloud Nuclei, J. Atmos. Sci., 26, 684-688, 1968.

van der Werf, G. R., Randerson, J. T., Giglio, L., Collatz, G. J., Mu, M., Kasibhatla, P. S., Morton, D. C., DeFries, R. S., Jin, Y., and van Leeuwen, T. T.: Global fire emissions and the contribution of deforestation, savanna, forest, agricultural, and peat fires (19972009), Atmos. Chem. Phys., 10, 11707-11735, doi:10.5194/acp10-11707-2010, 2010.

Weber, R. J., Guo, H. Y., Russell, A. G., and Nenes, A.: High aerosol acidity despite declining atmospheric sulfate concentrations over the past 15 years, Nat. Geosci., 9, 282-285, 2016.

Wurzler, S., Reisin, T. G., and Levin, Z.: Modification of mineral dust particles by cloud processing and subsequent effects on drop size distributions, J. Geophys. Res.-Atmos., 105, 45014512, 2000.

Xu, L. and Penner, J. E.: Global simulations of nitrate and ammonium aerosols and their radiative effects, Atmos. Chem. Phys., 12, 9479-9504, doi:10.5194/acp-12-9479-2012, 2012.

Yamashita, K., Murakami, M., Hashimoto, A., and Tajiri, T.: CCN Ability of Asian Mineral Dust Particles and Their Effects on Cloud Droplet Formation, J. Meteorol. Soc. Jpn., 89, 581-587, 2011.

Yienger, J. J. and Levy, H.: Empirical-model of global soil-biogenic $\mathrm{NO}_{x}$ emissions, J. Geophys. Res.-Atmos., 100, 11447-11464, 1995. 
Yin, Y. and Chen, L.: The effects of heating by transported dust layers on cloud and precipitation: a numerical study, Atmos. Chem. Phys., 7, 3497-3505, doi:10.5194/acp-7-3497-2007, 2007.

Zender, C. S. and Kwon, E. Y.: Regional contrasts in dust emission responses to climate, J. Geophys. Res., 110, D13201, doi:10.1029/2004JD005501, 2005.

Zhang, Y., Zhang, X., Wang, K., He, J., Leung, L. R., Fan, J., and Nenes, A.: Incorporating an advanced aerosol activation parameterization into WRF-CAM5: Model evaluation and parameterization intercomparison, J. Geophys. Res.-Atmos., 120, 6952-6979, 2015.
Zhao, C. S., Tie, X. X., Brasseur, G., Noone, K. J., Nakajima, T., Zhang, Q., Zhang, R. Y., Huang, M. Y., Duan, Y., Li, G. L., and Ishizaka, Y.: Aircraft measurements of cloud droplet spectral dispersion and implications for indirect aerosol radiative forcing, Geophys. Res. Lett., 33, L16809, doi:10.1029/2006GL026653, 2006. 